\title{
Does rapid glacial recession affect feeding habits of alpine stream insects?
}

Mirela Sertić Peric ${ }^{1 *}$, Jens M. Nielsen ${ }^{2+}$, Carsten J. Schubert ${ }^{3}$, Christopher T. Robinson ${ }^{3}$

1* Corresponding author: University of Zagreb, Faculty of Science, Department of Biology, Rooseveltov trg 6, 10000 Zagreb, Croatia, tel: +385 14877 705, E-mail: msertic@ biol.pmf.hr

${ }^{2}$ Queen Mary University of London, School of Biological and Chemical Sciences, London E1 4NS, United Kingdom, Email: jensmunielsen@gmail.com (+Present address: National Oceanic and Atmospheric Administration, Alaska Fisheries Science Center, 7600 Sand Point Way NE, Seattle, WA 98115, USA)

${ }^{3}$ Department of Surface Waters - Research and Management, Swiss Federal Institute of Aquatic Science and Technology (Eawag), Kastanienbaum, Switzerland, E-mail: carsten.schubert@eawag.ch

${ }^{4}$ Department of Aquatic Ecology, Swiss Federal Institute of Aquatic Science and Technology (Eawag), 8600 Dübendorf, Switzerland, and Institute of Integrative Biology, ETH-Zürich, 8092 Zürich, Switzerland, E-mail: christopher.robinson@eawag.ch

Running head: Feeding habits of alpine stream insects

Keywords: glacial streams, stream food webs, Baetis alpinus, Diamesinae, Rhithrogena spp.

This document is the accepted manuscript version of the following article:

Sertić Perić, M., Nielsen, J. M., Schubert, C. J., \& Robinson, C. T. (2021). Does rapid glacial recession affect feeding habits of alpine stream insects? Freshwater Biology, 66(1), 114-129.

https://doi.org/10.1111/fwb.13621 


\section{Summary}

1. Glacial retreat, accompanied by shifts in riparian vegetation and glacier meltwater inputs, alters the energy supply and trophic structure of alpine stream food webs. Our goal in this study was to enhance understanding of dietary niches of macroinvertebrates inhabiting different alpine streams with contrasting glacial and non-glacial (groundwater, precipitation, snowmelt) water inputs in conjunction with seasonal and habitat-specific variation in basal resource availability.

2. We measured a range of stream physico-chemical attributes as well as carbon and nitrogen isotopes $\left(\delta^{13} \mathrm{C}, \delta^{15} \mathrm{~N}\right)$ of macroinvertebrates and primary food sources at seven sites across seasons within a Swiss glaciated catchment (Val Roseg) undergoing rapid glacial retreat (1-2 km between years 1997-2014). Sampling sites corresponded to streams used in a previous (1997/1998) study within the same alpine catchment.

3. Physico-chemical attributes showed wide variation in environmental conditions across streams and seasons. Significant correlation among physico-chemical proxies of glacier meltwater $\left(\mathrm{P}^{-} \mathrm{PO}_{4}{ }^{3-}, \mathrm{TIC}\right.$, conductivity, turbidity) and macroinvertebrate $\delta^{13} \mathrm{C}, \delta^{15} \mathrm{~N}$ and $\mathrm{SEA}_{\mathrm{c}}$ (a proxy for feeding niche width) values showed that the extent of glacial water input shapes the energy base among alpine streams. Feeding niche differences among common alpine stream insect taxa (Chironomidae, Baetidae, Heptageniidae) were not significant, indicating that these organisms likely are plastic in feeding behaviour, opportunistically relying on food resources available in a particular stream and season.

4. Seasonal trends in macroinvertebrate $\delta^{13} \mathrm{C}$ largely followed patterns in periphyton $\delta^{13} \mathrm{C}$ values, indicating that autochthonous resources were the main consumer energy source within the stream network, as shown previously. The overall range in macroinvertebrate $\delta^{13} \mathrm{C}(-33.5$ to $-18.4 \%)$ and $\delta^{15} \mathrm{~N}$ (-6.9 to $6.7 \%$ ) values also corresponded to values measured in the previous study, suggesting that macroinvertebrates altered diets in line with changes in environmental conditions and food resources during a period of rapid glacial retreat. Our results suggest that environmental changes brought on by rapid glacial retreat have not yet caused a profound change in the trophic structure within these fluvial networks. 


\section{Introduction}

Global warming is rapidly diminishing glacier volumes, with clear impacts on the hydrology, biodiversity and ecological functioning of alpine ecosystems (Slemmons, Saros, \& Simon, 2013; Huss et al., 2017; Milner et al., 2017; Brighenti et al., 2019). Retreating glaciers are ubiquitous in alpine systems worldwide, including the European Alps, where it is predicted that only 4-13\% of the 2003 ice area will be present by 2100 (Zemp et al., 2006, 2019; Huss, 2012). Glacial streams respond rapidly to such environmental changes and are recognized as reliable early-warning indicators of ecosystems vulnerability to ongoing climate change (Beniston, 2003; IPCC, 2014; Khamis et al., 2014b; Giersch et al., 2017).

Future temperature increases and shifts in precipitation patterns (i.e., earlier snowmelt and more intensive rainfall instead of snow events) are predicted to cause substantial changes in seasonal and inter-annual thermal and hydrological regimes of glacial streams (Beniston \& Stoffel, 2016; Robinson et al., 2016). Furthermore, the existing glacier-fed (proglacial; kryal) streams are expected to become dominated by "warmer" non-glacial water sources, such as groundwater- (krenal) and precipitation-fed (rhitral) tributaries, and newly formed proglacial lake outlets (Milner, Brown, \& Hannah, 2009; Finn, Räsänen, \& Robinson, 2010; Sertić Perić \& Robinson, 2015; Shugar et al., 2017). In response to steepening thermal gradients and changes in precipitation regimes, alpine areas are also facing considerable upward altitudinal shifts (ca. 300 - 400 m) in tree-line vegetation (Holten \& Carey, 1992), which will likely increase terrestrial and woody allochthonous inputs to alpine streams that were previously supported by autochthonous and herbaceous allochthonous basal resources (cf. Hotaling et al., 2017 and references therein). This could further be coupled with upward shifts of stream biota (i.e., altitudinal expansion and more intensive competition of species from lower altitudes), leading to novel species assemblages that impact the structure, biodiversity and function of alpine fluvial ecosystems (Zah, Burgherr, Bernasconi, \& Uehlinger, 2001; Zah, Niederöst, Rinderpacher, \& Uehlinger, 2001; Milner, Brown, \& Hannah, 2009; Wookey et al., 2009; Finn, Räsänen, \& Robinson, 2010). Because riparian vegetation of glacier-fed streams above tree-line is typically sparse and/or characterised by higher abundance of shrub species adapted to harsh alpine environments (McKernan, 
Cooper, \& Schweiger, 2018), it is commonly thought that autochthonous organic material from in-

stream primary producers dominate basal resource inputs in most alpine streams, whereas allochthonous (terrestrial, riparian) resources become more important in downstream running waters with the presence of subalpine forests (Ward, 1994; Füreder, 1999; Zah, Burgherr, Bernasconi, \& Uehlinger, 2001; Zah, Niederöst, Rinderpacher, \& Uehlinger, 2001). However, different species (i.e., generalists, specialists) are differently impacted by changes in basal resource supply along alpine stream gradients (Zah, Burgherr, Bernasconi, \& Uehlinger, 2001; Khamis et al., 2014a; Niedrist \& Füreder, 2016, 2017). Food preferences of alpine stream macroinvertebrates also depend on local assemblage composition, competition intensity, including cannibalism in some taxa (e.g., Diamesinae), and the foraging flexibility of macroinvertebrate consumers (Clitherow, Carrivick, \& Brown, 2013; Cauvy-Fraunié et al., 2014, 2015; Fort \& Segura, 2017; Niedrist \& Füreder, 2018). Feeding niches of alpine aquatic insects commonly vary with stream habitat (stream type) and across seasons, due to spatio-temporal variation in primary production, prey and allochthounous carbon availability (Zah, Burgherr, Bernasconi, \& Uehlinger, 2001; Helland et al., 2011; Cutting, Cross, Anderson, \& Reese, 2016; Di Cugno \& Robinson, 2017). Many alpine macroinvertebrates (e.g., Baetidae such as Baetis alpinus, and Heptageniidae such as Rhithrogena sp and Ecdyonurus sp.) exhibit highly "plastic" feeding behaviours and a potential for opportunistic omnivory, whereas some taxa (e.g., Diamesinae) may actively select high quality food despite a harsh environment characterized by low rates of primary production, minimal allochthonous organic matter inputs and low predation (Zah, Burgherr, Bernasconi, \& Uehlinger, 2001; Clitherow, Carrivick, \& Brown, 2013; Di Cugno \& Robinson, 2017; Niedrist \& Füreder, 2017).

As alpine stream ecosystems continue to transform with ongoing glacial recession, they might reach a "tipping point" after which ecosystem biodiversity and food web structure could be profoundly impacted, whereby the present benefits of feeding plasticity may become limited due to resource limitation (cf. Scheffer et al., 2009; Domisch, Jähnig, \& Haase, 2011; Di Cugno \& Robinson, 2017). Thus, linking spatial (habitat-specific) and temporal (seasonal, inter-annual) patterns in resource availability and use among alpine streams can assist in detecting "losers and winners" during ongoing 
analyses are important towards understanding how and to what extent dietary niche shifts occur during rapid environmental change (sensu Opdam \& Wascher, 2004; Dudgeon, 2010; IPCC, 2014).

Here, we investigated diets of the most common macroinvertebrate taxa inhabiting streams with different glacial and non-glacial water inputs within an Alpine glacial catchment (Val Roseg, Switzerland) undergoing rapid glacial retreat (1-2 km between years 1997-2014; Swiss Glacier Monitoring Network; http://glaciology.ethz.ch/messnetz/glacierlist). Using physico-chemical and food resource data along with measures of carbon-nitrogen isotopes of macroinvertebrates across seasons at several sites representing different stream types, we examined the following questions. Firstly, do stream macroinvertebrates inhabiting different alpine streams exhibit significant seasonal differences in basal resource use? We hypothesized (H1) that in periods of unfavourable environmental conditions such as snow-cover in winter and glacier-melt accompanied by high discharge in summer, autochthonous food sources become limited and macroinvertebrates shift to allochthonous (terrestrial-sourced) organic material (cf. Zah, Burgherr, Bernasconi, \& Uehlinger, 2001; Zah, Niederöst, Rinderpacher, \& Uehlinger, 2001). Changes in basal resource assimilation would be reflected in isotope values $\left(\delta^{13} \mathrm{C}, \delta^{15} \mathrm{~N}\right)$ of macroinvertebrate consumers. Secondly, do alpine stream macroinvertebrates change food sources and trophic niche width across different alpine streams that have habitat-specific differences in basal resource inputs? Here, we hypothesized (H2) that macroinvertebrate feeding niches would be broader in glacier-fed streams with sparse riparian vegetation (due to generalist feeding behaviours) than in groundwater-fed and/or downstream reaches with a broader array of resources available, which could support specialist feeding behaviours. Lastly, by comparing our findings with a previous study in the same catchment (Zah, Burgherr, Bernasconi, \& Uehlinger, 2001), we evaluated whether alpine stream food webs and feeding habits of stream insects have changed during recent glacial retreat over the last 20 years.

\section{Methods}

\section{Study site description}

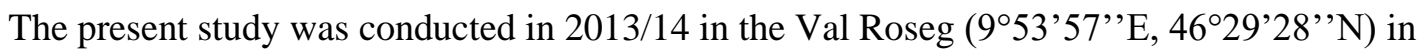
southeast Switzerland (Fig. 1). The upper Val Roseg is ca. $2750 \mathrm{~m}$ long, 100-500 m wide, with 
elevations ranging from 1995 to $2100 \mathrm{~m}$ a.s.l. among study sites. Along this altitudinal gradient, vegetation ranges from areas dominated by pioneer plants (lichens, mosses) and patchy grasses within the subnival, low-alpine zone to dense subalpine forests of larch (Larix decidua Mill.) and pine (Pinus mugo Turra, Pinus cembra L.) at lower floodplain hillslopes (Ward \& Uehlinger, 2003). Sporadic shrubs of green alder (Alnus viridis (Chaix.) D.C.), willow (Salix spp.) and common juniper (Juniperus communis L.) as well as early successional stages of the larch occur in the low-alpine zone.

The fluvial network arises from two glacier-fed streams: 1) a proglacial (kryal) stream originating from Tschierva glacier, and 2) a lake outlet originating from a proglacial lake (area $=0.36$ $\mathrm{km}^{2}$, depth $=$ ca. $7 \mathrm{~m}$, altitude $=2159 \mathrm{~m}$ ) fed by Roseg glacier. The two glaciers have decreased rapidly in size over time (Fig. 1); Tschierva retreated $764 \mathrm{~m}$ and Roseg 2024 m between 1997-2014 (Swiss Glacier Monitoring Network; http://glaciology.ethz.ch/messnetz/glacierlist), which represents the general contemporary trend of intensive glacier reduction in the European Alps. Below the confluence of the proglacial (kryal) stream (length ca. $900 \mathrm{~m}$ ) and proglacial lake outlet (length ca. $950 \mathrm{~m}$ ), the Roseg river forms a single main channel incised in glacial till (length ca. $600 \mathrm{~m}$ ). Downstream, the channel broadens as a braided river floodplain receiving water from various side-valley tributaries (krenal, rhithral). The river then converges as a canyon-constrained channel (length ca. $7050 \mathrm{~m}$ ) merging with the Inn River at Pontresina (Fig. 1). Mean annual discharge of Roseg at the gauging station Rosegbach (located in Pontresina; Fig. 1) was $2.94 \mathrm{~m}^{3} \mathrm{~s}^{-1}$ (range 0.03-12.4 $\mathrm{m}^{3} \mathrm{~s}^{-1}$ ) (1997-2014; Swiss Federal Office of the Environment). The flow regime has a well-defined seasonal pattern, reaching annual maxima in late spring and summer, and minima in winter (see Sertić Perić \& Robinson, 2015).

The seven study sites were spread along a vegetation gradient from the glacier snouts to the end of the Roseg catchment at Pontresina (Fig. 1, Table 1). Site names refer to stream types: L1 and L2 are lake outlet sites (upper and lower reach, respectively), $\mathrm{P}$ is the proglacial stream, T1 and T2 are respective krenal and rhithral tributaries, and M1 and M2 are main channel sites. Sites L1, L2 and P were in the subnival zone, whereas T1, T2, M1 and M2 were spread across the low-alpine and subalpine zone. Physical and chemical characterization of each site is given in Tables 1 and 2. Sites labeled L1, T1, M1 and M2 in this paper correspond to sites L10, G1, M20 and M40, respectively, used in the 

new additions in this study.

Field sampling protocol

Field sampling was completed on 20 November 2013 (autumn; A), and 7 March (winter; W), 22

114 May (spring; SP) and 17 July (summer; SU) 2014. In winter, sampling was not possible for some

115 streams because sites were either inaccessible (L2, P) or dry (T2). On each sampling date and site, we measured water temperature, electrical conductivity $\left(\right.$ Cond at $\left.20^{\circ} \mathrm{C}\right)$, and turbidity as nephelometric turbidity units (NTU) using portable field meters (WTW model LF325, Weilheim, Germany; Cosmos, Züllig AG, Switzerland; accuracy: $\pm 0.5 \%$ of value for all parameters). Further, a $0.5 \mathrm{~L}$ water sample was collected for chemical analysis in the laboratory. Water samples were stored in polyethylene bottles, transported in a cool box to the lab, and analysed for nitrate- $\mathrm{N}\left(\mathrm{NO}_{3}{ }^{-}-\mathrm{N}\right)$, phosphate- $\mathrm{P}\left(\mathrm{PO}_{4}{ }^{3-}-\mathrm{P}\right)$, dissolved organic carbon (DOC), total organic carbon (TOC), and total inorganic carbon (TIC) following methods in Tockner et al. (1997).

With an aim to gain comparable data sets through investing the same research effort at each site and date, macroinvertebrates were collected with a three minute kick/sweep sample using a standard kick-net (mesh size: $250 \mu \mathrm{m}$ ), followed by a three minute manual search at multiple areas within each site. From each sample, individual taxa were separated manually and stored in individual containers at $4^{\circ} \mathrm{C}$ overnight for gut evacuation. At each site, 2-20 individuals of each common taxa, depending on body size, were collected (i.e., 2-3 individuals had to be collected for larger taxa, such as Heptageniidae, whereas about 20, individuals had to be collected for a few smaller taxa such as Chironomidae and Baetidae). On average, there were $6.2 \pm 0.7$ (mean \pm SE) dominant taxa per site (see Table 2). A total of 13 macroinvertebrate taxa from the 7 study sites were classified as non-predatory taxa, and 9 taxa were classified as predators. The next day, most collected specimens were frozen $\left(-25^{\circ} \mathrm{C}\right)$ for later isotope analysis, and some individuals were stored in $70 \%$ ethanol for identification to the lowest possible taxonomic level in the lab. Identifications were based on Tachet, Richoux, Bournard, \& UsseglioPolatera (2010). 

resources included periphyton, coarse particulate organic matter (CPOM, >1 mm), fine particulate organic matter (FPOM, $<1 \mathrm{~mm}$ ), riparian grasses, and leaves/needles from shrubs and trees. Riparian vegetation was sampled during the vegetation season (summer, autumn). For periphyton, 3-5 rocks with visible biofilm were scrubbed with a metal brush, all invertebrates were carefully removed if present.

141 CPOM was sampled as leaf litter and branches in the stream, and FPOM was collected as detritus from 142 the stream bed in slow-flowing areas. All organic matter samples were stored at $-25^{\circ} \mathrm{C}$ until processed 143 for isotope analysis.

\section{Laboratory analysis of stable isotopes} values. All macroinvertebrate and organic resource samples for isotope analysis were dried at $60^{\circ} \mathrm{C}$ and ground to a fine powder. Then, two replicates of each sample (each $0.5 \pm 0.05 \mathrm{mg}$ for macroinvertebrates, $1.5 \pm 0.05 \mathrm{mg}$ for organic resources) were placed in separate $8 \times 5 \mathrm{~mm}$ tin capsules and analysed using a ThermoQuest NC 2500 elemental analyser connected via an open split to a Micromass mass spectrometer (Isoprime). For isotope analysis of large taxa (i.e., Perlodidae, Rhyacophilidae, Pediciidae, Limoniidae, Heptageniidae), 2-5 individuals were used, whereas at least 10 individuals were pooled for smaller taxa (i.e., Chironomidae, Simuliidae, Baetidae). In total, 233 macroinvertebrate and 85 resource samples were analysed for carbon $\left(\delta^{13} \mathrm{C}\right)$ and nitrogen $\left(\delta^{15} \mathrm{~N}\right)$ stable isotopes. Isotope data were expressed in delta notation $(\delta)$ as $\left[\left(\mathrm{R}_{\text {sample }} / \mathrm{R}_{\text {standard }}\right)-1\right]$ x 1000 , where $\mathrm{R}$ is the ratio of heavy to light isotope $\left({ }^{13} \mathrm{C}:{ }^{12} \mathrm{C},{ }^{15} \mathrm{~N}:{ }^{14} \mathrm{~N}\right) . \mathrm{R}_{\text {sample }}$ is the ratio of the sample, and $\mathrm{R}_{\text {standard }}$ is the ratio of the used laboratory standard. Measured values were calibrated with sulfanilic acid $\left(\mathrm{C}_{6} \mathrm{H}_{7} \mathrm{NO}_{3} \mathrm{~S} ; \delta^{15} \mathrm{~N}\right.$ $=2.01 \%$ ) reference material for nitrogen and DAN1 sediment (an internal working standard calibrated to $\mathrm{VPDB})\left(\delta^{13} \mathrm{C}=-14.71 \%\right.$ ) for carbon. All values are reported as delta values in relation to the international standards (atmospheric air for nitrogen and Vienna Pee Dee Belemnite (VPDB) for carbon). All individual isotope values are found in Tables S1 and S2, along with information on 
macroinvertebrate groups and organic resource data. Because lipids normally have lower carbon isotope values, they have a potential to bias the $\delta^{13} \mathrm{C}$ isotope values of animals, thus a mathematical normalization technique was used to standardize lipid content on $\delta^{13} \mathrm{C}$, as proposed by McConnaughey \& McRoy (1979).

We calculated isotope niche areas using the $\delta^{15} \mathrm{~N}$ and $\delta^{13} \mathrm{C}$ isotope values in SIBER (Jackson, Parnell, Inger, \& Bearhop, 2011). Isotope niche estimates are measures of ellipses in bivariate isotope space and provide a proxy for the niche width of consumers, though individual outliers may not necessarily be accurately reflected by these estimates (Layman \& Allgeier, 2012). Estimates included standard ellipse areas (SEA), corrected SEA values $\left(\mathrm{SEA}_{\mathrm{c}}\right)$, and Bayesian estimate of SEA $\left(\mathrm{SEA}_{\mathrm{b}}\right)$ (Layman, Arrington, Montaña, \& Post, 2007; Jackson, Parnell, Inger, \& Bearhop, 2011) for consumers within each stream and season (Tables S1, S2). We estimated isotope niche parameters when sample size for a given site was above 5 (after Jackson, Parnell, Inger, \& Bearhop, 2011). Both SEA $\mathrm{A}_{c}$ and SEA are particularly useful when dealing with unequal sample sizes, as was the case here (Jackson, Parnell, Inger, \& Bearhop, 2011).

\section{Data analysis}

Physico-chemical measures and macroinvertebrate taxa richness (number of taxa) at each site were summarized as means (across seasons), standard errors (SE), minima (MIN), maxima (MAX), and coefficients of variation $(\mathrm{CV})$. In line with many previous alpine stream ecology studies and more than 20 years of ecological investigation in the Val Roseg catchment (e.g., Ward, 1994), we used physicochemical measures as proxies of glacial and non-glacial water inputs among sites, stream types, and seasons. Thereby, glacier meltwater inputs commonly show low and fluctuating stream temperatures, increased discharge and turbidity during summer glacier melt. In contrast, snowmelt- and precipitationfed streams tend to exhibit more moderate environmental conditions reflected in relatively higher water temperatures, and lower flow fluctuations and turbidity. Groundwater-fed streams are often relatively warm and clear waters with rather constant and stable water temperature, flow and turbidity during the entire year (Ward, 1994; Tockner et al., 1997). To illustrate differences among sites in relation to water 
source (glacial, snowmelt, precipitation, groundwater) influence, the physico-chemical measurements were ordinated using a principal components analysis (PCA). All data were $\log (\mathrm{x}+1)$ transformed prior to running the PCA.

Due to the low number of sites, a non-parametric Kruskal-Wallis (K-W) test was used to examine spatial (site, stream type) and temporal (season) differences in physico-chemical measures as well as carbon $\left(\delta^{13} \mathrm{C}\right)$ and nitrogen $\left(\delta^{15} \mathrm{~N}\right)$ stable isotope ratios, and isotope niche width parameters (SEA, SEA, $\mathrm{SEA}_{\mathrm{b}}$ ). A multiple comparison post hoc procedure was used significant to depict differences among specific groups. The K-W test requires no distributional assumptions and corresponds to an ANOVA by ranks (Sokal \& Rohlf, 1995). Because riparian vegetation was sampled only in summer and autumn, a non-parametric Mann-Whitney-U (M-W) test was used to examine seasonal differences in stable isotope values. Significance level (p-value) was set at 0.05 for all tests. Lastly, linear relationships between physico-chemical variables, stable isotope ratios and isotope niche parameters were examined using a Spearman's rank correlation, as a non-parametric equivalent to linear regression analysis commonly used for confirming a small number of expected results (Sauro \& Lewis, 2016). Site, sampling site*season and stream type*season data were used in the correlation analysis. All statistical analysis were performed with Statistica 9.1, StatSoft, 2010.

\section{Results}

\section{Environmental conditions of study sites}

The physico-chemical attributes showed large variability in environmental conditions across study sites, stream types and seasons. Mean water temperature measured during the sampling period ranged from 2.9 to $6.4^{\circ} \mathrm{C}$ among sites, being lowest in the proglacial (P) stream (Table 2). Mean turbidity ranged from 2.0 to 158 NTUs, with higher values reflecting glacier meltwater inputs at sites P, $\mathrm{M} 1$, and M2. Conductivity values ranged from 38 to $73 \mu \mathrm{S} / \mathrm{cm}$. Mean DOC was low, ranging from 0.53 to $0.90 \mathrm{mg} \mathrm{C} \mathrm{L}^{-1}$, and mean TOC ranged from 0.58 to $0.97 \mathrm{mg} \mathrm{C} \mathrm{L}^{-1}$. Mean TIC ranged from 4.6 to 7.6 $\mathrm{mg} \mathrm{C} \mathrm{L}{ }^{-1}$. Nitrate levels typically were less than $0.25 \mathrm{mg} \mathrm{N} \mathrm{L}^{-1}$, and mean ortho-phosphorous levels ranged from 1.1 to $4.2 \mu \mathrm{g} \mathrm{P} \mathrm{L}{ }^{-1}$ (Table 2). 
Mean water temperatures of all sites was higher in summer (mean $=8.9 \pm 3.8^{\circ} \mathrm{C}$ ) than autumn

$217\left(2.8 \pm 0.9^{\circ} \mathrm{C}\right)$ and winter $\left(1.3 \pm 1.1^{\circ} \mathrm{C}\right)\left(\mathrm{K}-\mathrm{W}\right.$ test: $\left.H_{(3, \mathrm{~N}=25)}=15.12, \mathrm{p}=0.002\right)$, whereas conductivity 218 was lower in summer $\left(\right.$ mean $\left.=45.3 \pm 9.2 \mu \mathrm{S} \mathrm{cm}^{-1}\right)$ than winter $\left(88.8 \pm 17.8 \mu \mathrm{S} \mathrm{cm}^{-1}\right)\left(H_{(3, \mathrm{~N}=25)}=10.77\right.$, $219 \mathrm{p}=0.013)$. Summer TIC values (mean $\left.=5.16 \pm 0.36 \mathrm{mg} \mathrm{C} \mathrm{L}^{-1}\right)$ were lower than in winter $(8.59 \pm 2.01$ $\left.\operatorname{mg~C~L}{ }^{-1}\right)\left(H_{(3, \mathrm{~N}=24)}=8.94, \mathrm{p}=0.030\right)$, and TOC was higher in spring $\left(1.02 \pm 0.31 \mathrm{mg} \mathrm{C} \mathrm{L}^{-1}\right)$ than winter $\left(0.50 \pm 0.00 \mathrm{mg} \mathrm{C} \mathrm{L}^{-1}\right)$ and summer $\left(0.60 \pm 0.10 \mathrm{mg} \mathrm{C} \mathrm{L}^{-1}\right)\left(H_{(3, \mathrm{~N}=24)}=16.65, \mathrm{p}=0.001\right)$.

The first two PCA-axes explained $65.3 \%$ of the total variation in the physico-chemical variables among sites (Fig. 2). PCA axis-1 aligned sites along a gradient of decreasing temperature, and increasing conductivity and TIC. Tributary T2 displayed the highest temperature and lowest TIC and conductivity values among sites. Among glacier-fed sites, lake outlet sites (L1, L2) showed higher temperatures and lower TIC and conductivity values than the main channel (M1, M2) and proglacial (P) sites. Tributary sites were separated from glacier-fed sites along PCA-2, having lower turbidity, and higher DOC and TOC than the other sites. Temporal variation, as shown by the error bars in the PCA, was highest at T1, whereas the lake outlet sites (L1, L2) had the lowest temporal variation (Fig. 2).

Organic resource isotope composition among streams

Isotope $\delta^{13} \mathrm{C}$ ratios of periphyton ranged from -33.08 to $-16.01 \%$ across all seasons and sites, and were lower at main channel than lake outlet and proglacial sites (K-W test: $H_{(6, \mathrm{~N}=32)}=20.18, \mathrm{p}=$ 0.0002) (Fig. 3). Isotope $\delta^{13} \mathrm{C}$ values of riparian vegetation ranged from -28.23 to $-14.46 \%$, with lower values at the lake outlets than main channel sites $\left(H_{(4, \mathrm{~N}=24)}=12.11, \mathrm{p}=0.017\right)$. Detritus $(\mathrm{CPOM}+\mathrm{FPOM}) \delta^{13} \mathrm{C}$ values ranged from -30.18 to $-26.18 \%$ across seasons and sites, and did not differ among sites $\left(H_{(6, \mathrm{~N}=29)}=16.21, \mathrm{p}=0.40\right)$ or stream types $\left(H_{(3, \mathrm{~N}=29)}=6.18, \mathrm{p}=0.103\right)$. Isotope $\delta^{15} \mathrm{~N}$ ratios ranged from -6.41 to $0.72 \%$ for periphyton, -6.01 to $-1.78 \%$ for detritus, and -7.26 to $1.3 \%$ for riparian vegetation (Fig 3). The $\delta^{15} \mathrm{~N}$ values for organic resources did not differ among stream types (KW test: $p>0.05)$. 

taxa at the study sites ranged from 3.7 (site P) to 8.3 (T2) (Table 2). The taxa found at most sites during all four seasons were Chironomidae, Baetis alpinus (Baetidae) and Rhithrogena spp. (Heptageniidae) (Table 3). The $\delta^{13} \mathrm{C}$ values of all macroinvertebrates across all study sites and seasons ranged from 33.46 to $-18.40 \%$ (mean \pm SD: $-26.24 \pm 2.88 \%$ ), and $\delta^{15} \mathrm{~N}$ values from -6.91 to $6.69 \%$ o $(-0.83 \pm 2.49$ \%o) (Fig. 4a). There were significant differences in macroinvertebrate $\delta^{13} \mathrm{C}$ and $\delta^{15} \mathrm{~N}$ values among individual sites (Table S3) and stream types (Fig. 4a; K-W test: $\mathrm{H}_{(3, \mathrm{~N}=233)}=62.97, \mathrm{p}<0.0001$ ). Highest $\delta^{13} \mathrm{C}$ values for macroinvertebrates were observed at the proglacial $(\mathrm{P})$ stream, moderate values at tributary and lake outlet sites, and lowest at main channel sites (Fig. 4a). Isotope $\delta^{15} \mathrm{~N}$ values also differed significantly among stream types $\left(\mathrm{H}_{(3, \mathrm{~N}=233)}=89.67, \mathrm{p}<0.001\right)$, being highest at the lake outlet sites, moderate at tributary sites, and lowest at main channel and proglacial sites (Fig. 4a). Baetidae, i.e., Baetis alpinus; Heptageniidae, i.e., Rhithrogena spp. $)\left(\mathrm{K}-\mathrm{W}\right.$ test: $H_{(2, \mathrm{~N}=104)}=3.28, \mathrm{p}=$ 0.194) (Fig. 4b-d). However, isotope $\delta^{15} \mathrm{~N}$ values were significantly higher for Heptageniidae relative to Chironomidae and Baetidae $\left(H_{(3, \mathrm{~N}=104)}=25.98, \mathrm{p}<0.0001\right)\left(\right.$ Fig. 4). The $\delta^{15} \mathrm{~N}$ values for Chironomidae did not differ among sites $\left(H_{(6, \mathrm{~N}=28)}=18.12, \mathrm{p}=0.061\right)$ or stream types $\left(H_{(6, \mathrm{~N}=28)}=9.65, \mathrm{p}=0.060\right)$. However, isotope $\delta^{13} \mathrm{C}$ values for Chironomidae were higher at the proglacial $(\mathrm{P})$ stream than the main channel sites (M1: $\left.H_{(6, \mathrm{~N}=28)}=15.30, \mathrm{p}=0.018 ; \mathrm{M} 2: H_{(3, \mathrm{~N}=28)}=13.12, \mathrm{p}=0.004\right)$ (Fig. 4b). Baetidae had higher $\delta^{13} \mathrm{C}$ values at site $\mathrm{P}$ than at $\mathrm{L} 1$ and $\mathrm{M} 1\left(H_{(6, \mathrm{~N}=40)}=23.55, \mathrm{p}=0.0006\right)$, whereas $\delta^{15} \mathrm{~N}$ values were lower at M1 than at L1 and L2 $\left(H_{(3, \mathrm{~N}=40)}=17.15, \mathrm{p}=0.0007\right)$, and lower at site $\mathrm{P}$ than at $\mathrm{L} 1\left(H_{(6, \mathrm{~N}}\right.$ $=40)=24.29, \mathrm{p}=0.0005)($ Fig. $4 \mathrm{c})$. Heptageniidae had higher $\delta^{13} \mathrm{C}$ values at site $\mathrm{P}$ than at sites $\mathrm{M} 1$ and L1 $\left(H_{(5, \mathrm{~N}=36)}=13.66, \mathrm{p}=0.018\right)$, but not among stream types $\left(H_{(5, \mathrm{~N}=36)}=6.98, \mathrm{p}=0.073\right)($ Fig. $4 \mathrm{~d})$. Heptageniidae $\delta^{15} \mathrm{~N}$ values were higher at lake outlet sites than at proglacial, tributary and main channel sites $\left(H_{(5, \mathrm{~N}=36)}=30.44, \mathrm{p}<0.0001\right)$. Lastly, SEA, SEA $\mathrm{c}$ and $\mathrm{SEA}_{\mathrm{b}}$ values were not significantly different among stream types, either for all macroinvertebrates or for Chironomidae, Baetidae and Heptageniidae (Table S1, S2). related to $\delta^{13} \mathrm{C}, \delta^{15} \mathrm{~N}$ and isotope niche parameter $\mathrm{SEA}_{\mathrm{c}}$ (Fig. 5). Isotope $\delta^{13} \mathrm{C}$ values were positively 
271 correlated to $\mathrm{PO}_{4}{ }^{3-} \mathrm{P}$, isotope $\delta^{15} \mathrm{~N}$ values were negatively correlated to TIC and conductivity, and SEA

272 was negatively correlated to turbidity. There were no significant relationship between other physico-

273 chemical parameters (Table 2) and $\delta^{13} \mathrm{C}, \delta^{15} \mathrm{~N}, \mathrm{SEA}, \mathrm{SEA}, \mathrm{SEA}_{\mathrm{c}}$.

Seasonality in carbon and nitrogen isotope ratios

There were no significant seasonal differences in detrital (CPOM+FPOM) $\delta^{13} \mathrm{C}$ and $\delta^{15} \mathrm{~N}$ values 277 (K-W test: $\mathrm{p}>0.05$ ) (Fig. 6). Periphyton $\delta^{13} \mathrm{C}$ values were lowest in winter relative to the other seasons $\left(H_{(3, \mathrm{~N}=32)}=3.62, \mathrm{p}=0.305\right)$ and the respective $\delta^{15} \mathrm{~N}$ values were highest in summer $\left(H_{(3, \mathrm{~N}=32)}=9.29, \mathrm{p}\right.$ $=0.026)$. Both $\delta^{13} \mathrm{C}$ and $\delta^{15} \mathrm{~N}$ values of riparian vegetation were higher in autumn than summer $\left(\delta^{13} \mathrm{C}\right.$, M-W test: $\mathrm{p}=0.009 ; \delta^{15} \mathrm{~N}, \mathrm{M}-\mathrm{W}$ test: $\left.\mathrm{p}=0.015\right)$ (Fig. 6). $\mathrm{N}=233)=52.50, \mathrm{p}<0.0001$ ), whereas the respective $\delta^{15} \mathrm{~N}$ values were significantly lower in autumn than in the other seasons $\left(H_{(3, \mathrm{~N}=233)}=31.85, \mathrm{p}<0.0001\right)$ (Fig. 6). Heptageniidae showed no seasonal differences in $\delta^{13} \mathrm{C}$ values $\left(H_{(3, \mathrm{~N}=36)}=0.56, \mathrm{p}=0.906\right)$, whereas Baetidae $\left(H_{(3, \mathrm{~N}=40)}=12.97, \mathrm{p}=0.005\right)$ and Chironomidae $\left(H_{(3, \mathrm{~N}=28)}=7.58, \mathrm{p}=0.05\right)$ had lowest $\delta^{13} \mathrm{C}$ values in winter. No seasonal differences were found in $\delta^{15} \mathrm{~N}$ values (K-W test: $\left.\mathrm{p}>0.05\right)$ for Chironomidae, Baetidae and Heptageniidae, although we observed lower $\delta^{15} \mathrm{~N}$ values in autumn relative to other seasons (Fig. 6). In spring and summer, mean $\delta^{13} \mathrm{C}$ values of all macroinvertebrates $(-26.50 \pm 2.78 \%$ ) were closer to detrital $(-27.94 \pm 1.25 \%$ ) and riparian vegetation $(-27.66 \pm 0.36 \%)$ than to periphyton $\delta^{13} \mathrm{C}(-23.19 \pm 4.45 \%$ ) values. Heptageniidae had on average higher $\delta^{15} \mathrm{~N}$ values than Baetidae and Chironomidae across seasons $\left(H_{(2, \mathrm{~N}=33)}=10.50, \mathrm{p}\right.$ $=0.005)$ (Fig. 6). Lastly, none of the macroinvertebrate niche parameters (SEA, SEA,$\left.S A_{b}\right)$ showed seasonal differences (K-W test, $\mathrm{p}>0.05)$ (Table $\mathrm{S} 1)$.

\section{Discussion}


with similar environmental conditions within the fluvial network. Variability in mean temperature,

turbidity, conductivity, TOC and $\mathrm{PO}_{4}{ }^{3-} \mathrm{P}$ among sites indicated differences in groundwater, snowmelt, precipitation and glacier-melt inputs among different stream types (as reported by Tockner et al., 1997; environmental gradients likely reflect changes in the amount of glacial meltwater influence, as observed in rapidly changing glacierized catchments worldwide (Milner, Brown, \& Hannah, 2009; Cauvy-Fraunié et al., 2014, 2015; Robinson et al., 2016). Increased turbidity, phosphorus and TIC in the proglacial stream mostly correspond to glacier meltwaters, which usually peak during summer (Burgherr \& Ward, 2001; Sertić Perić, Jolidon, Uehlinger, \& Robinson, 2015). Increased organic carbon (DOC, TOC), low turbidity, and less variable temperature and conductivity at site $\mathrm{T} 2$ indicate that this site is krenal (groundwater-fed), while more fluctuating environmental parameters at $\mathrm{T} 1$ indicate a rhithral (snowmelt-/precipitation-fed) character (cf. Malard, Tockner, \& Ward, 1999; Jantze, Laudon, Dahlke, \& Lyon, 2015).

315 influenced by temporal shifts in glacial meltwater inputs, and periphyton and riparian vegetation 316 development. For example, a significant negative correlation between turbidity and macroinvertebrate 317 feeding niche width indicates that periods of reduced access to periphyton, such as the summer glacier 318 melt period accompanied by higher turbidity, may cause changes in feeding habits (i.e., isotope niche 319 widths) of primary consumers. This is likely because the seasonally increased turbidity limits light penetration and periphyton development in our streams (Uehlinger, Robinson, Hieber, \& Zah, 2010;

321 Burpee, Anderson, \& Saros, 2018), which is then further reflected in consumer $\delta^{13} \mathrm{C}$ and $\delta^{15} \mathrm{~N}$ values.

$$
\text { We observed opposite trends between } \delta^{13} \mathrm{C} \text { and } \delta^{15} \mathrm{~N} \text { values across seasons and a significant }
$$

323 decrease in winter $\delta^{13} \mathrm{C}$ values for periphyton and most stream macroinvertebrates. The winter decrease in $\delta^{13} \mathrm{C}$ values was likely due to seasonal changes in the composition of periphyton (bacteria and algae) 
which store high amounts of dissolved and particulate organic carbon and nutrients (Flemming,

326 Wingender, \& Mayer, 2000; Donlan, 2002; Wu, 2016). Gibson \& Prowse (2002) also recorded low $\delta^{13} \mathrm{C}$ 327 values in winter, and suggested it was due to an increase of groundwater inputs during the freeze period, 328 which can greatly influence the heavy vs. light carbon isotope ratios due to a number of subsurface 329 biotic and abiotic processes, including oxidation of microbial- and rock-derived organic matter (Nowak et al., 2017). Contrarily, Hill \& Middleton (2006) concluded that stable carbon isotope variability is 331 associated with the natural variability in periphyton thickness, which is greatly influenced by: (i) 332 scouring spate events (causing a decrease in mean periphytic $\delta^{13} \mathrm{C}$ values); (ii) stream temperature 333 increase (causing a smaller, longer-term periphyton $\delta^{13} \mathrm{C}$ increase); and (iii) depletion of dissolved 334 inorganic carbon (DIC) within the periphyton (causing an increase of periphytic $\delta^{13} \mathrm{C}$ as the periphyton 335 biomass develops). Considering the rising $\delta^{13} \mathrm{C}$ values during periphyton biomass development (i.e., in 336 autumn and spring) in our study, it is likely that in our study system the seasonal depletion of DIC 337 within the periphyton matrix occurred (Hill \& Middleton, 2006). The observed $\delta^{15} \mathrm{~N}$ values might also 338 have been affected by the periphyton development and availability. For example, certain periphyton 339 community members found to be abundant components of alpine freshwater ecosystems in temperate 340 regions (i.e., cyanobacteria; cf. Aigner, Herburger, Holzinger, \& Karsten, 2018), can fix atmospheric 341 nitrogen, which is ${ }^{15} \mathrm{~N}$-depleted relative to organic and sedimentary nitrogen (Handley \& Raven, 1992). A more detailed insight into the periphyton community structure is needed for a more complete 343 understanding of the observed periphytic carbon and nitrogen stable isotope ratios. However, it is likely 344 that the increased spring periphyton biomass observed in our study included cyanobacteria growth, 345 which may have led to the decreased periphytic $\delta^{15} \mathrm{~N}$ values (cf. Handley \& Raven, 1992). Also, 346 considering the relatively wide and overlapping $\delta^{13} \mathrm{C}$ ranges of the main basal resource types/categories 347 (periphyton, detritus, riparian vegetation), it would be beneficial to analyse specific items of the basal resources and/or to supplement the stable isotope analysis with gut content analysis. However, gut 349 content analysis is better suited for the assessment of daily to weekly variation in consumption (as it 350 mainly represents consumption over the preceding 6-48 hours), while stable isotope analyses generally 351 integrate assimilation across longer timescales (Hayden, Harrod, \& Kahilainen, 2014). Integrating 352 information from both stable isotope and gut content analyses could provide a more detailed insight into 
the flexibility of macroinvertebrate consumers' diets, and assist in disentangling the potential temporal

354 (seasonal) and species-specific differences in diets and food assimilation (e.g., Lancaster \& Waldron, 355 2001; Nielsen et al., 2018).

Macroinvertebrate feeding niches across streams with different resource availability

Differing $\delta^{13} \mathrm{C}$ values between consumers and food resources among different stream types

suggest that: 1) most macroinvertebrates feed predominately on periphyton in the proglacial stream; and

2) consumers rely more on detritus and riparian vegetation in the lake outlet, main channel and tributary streams. The former is consistent with findings from other studies conducted in alpine streams above tree-line (Zah, Burgherr, Bernasconi, \& Uehlinger, 2001; Füreder, Welter, \& Jackson, 2003; Robinson,

363 Schmid, Svoboda, \& Bernasconi, 2008), whereas the latter corresponds to the results obtained in non-

364 glacial and streams below tree-line (Füreder, Welter, \& Jackson, 2003; Di Cugno \& Robinson, 2017).

365 However, due to high inter-site variation in periphyton and riparian vegetation $\delta^{13} \mathrm{C}$ values, and

366 seasonality in basal resource and consumer isotope ratios, a simple overlap of resource and consumer

$367 \quad \delta^{13} \mathrm{C}$ values might lead to false interpretations in consumer diet composition. Below we provide potential explanations for our findings and discuss possible sources of biases in our data.

The observed differences in periphyton and riparian vegetation $\delta^{13} \mathrm{C}$ values among study streams 370 corresponded with most previous alpine stream studies (Zah, Burgherr, Bernasconi, \& Uehlinger, 2000, 371 2001; Füreder, Welter, \& Jackson, 2003; Rott, Cantonati, Füreder, \& Pfister, 2006; Di Cugno \& 372 Robinson, 2017; Niedrist \& Füreder, 2017). Periphyton $\delta^{13} \mathrm{C}$ values (-33 to $-16 \%$ ) match earlier 373 (1997/1998) findings by Zah, Burgherr, Bernasconi, \& Uehlinger (2001), who indicated that more 374 negative $\delta^{13} \mathrm{C}$ values (-35 to $-25 \%$ ) emerge from the common filamentous alga Hydrurus foetidus and 375 more positive values (-25 to $-15 \%$ ) from epilithic diatoms. Indeed, main channel sites (M1, M2) were 376 densely covered with H. foetidus (M. Sertić Perić, personal observation) compared to the proglacial (P) 377 and lake outlet (L1, L2) sites. This difference in composition might have caused the among-site 378 differences in periphyton $\delta^{13} \mathrm{C}$ values as well as in macroinvertebrates (Zah, Burgherr, Bernasconi, \& 379 Uehlinger, 2001). Furthermore, among-site differences in riparian vegetation $\delta^{13} \mathrm{C}$ values (ranging from 
-28 to $-21 \%$ ) indicated shifts in riparian vegetation distribution along stream gradients. For example, the lake outlet sites (L1, L2), bounded by patchy grasses, had lower riparian vegetation $\delta^{13} \mathrm{C}$ values than main channel sites (M1, M2) bounded by coniferous woody vegetation. The higher $\delta^{13} \mathrm{C}$ mean values were measured for Larix (-24\%) at site M2, whereas lower $\delta^{13} \mathrm{C}$ values (-28 to $-27 \%$ ) were likely from grasses and herbs (e.g., Epilobium and Rumex) at L1, as reported in the earlier study of Zah, Burgherr, Bernasconi, \& Uehlinger (2001). On the other hand, Finlay \& Kendall (2007) reported that average $\delta^{13} \mathrm{C}$ values of terrestrial C3 plants (deciduous and coniferous trees) is around $-27 \%$, whereas values for terrestrial C4 plants (grasses and plants inhabiting semi-arid regions) is around $-13 \%$. Our results confirm that riparian vegetation in alpine ecosystems varies greatly in terms of isotope composition, likely due to site-specific and seasonal variation in local hydrology, productivity, metabolism, and contributions of groundwater versus soil runoff in streams (Finlay \& Kendall, 2007 and references therein).

Differences in the composition of basal resources among sites and stream types were also reflected in the high variation in macroinvertebrate carbon and nitrogen isotope values. It further corresponded to estimates of feeding niche widths of respective macroinvertebrate consumers (sensu Syväranta \& Jones, 2008). Feeding niche widths of Chironomidae were wider than those of Baetidae and Heptagenidae across our study streams. This indicates that Chironomidae (a common group of alpine aquatic insects; Milner, Brittain, Castella, \& Petts, 2001) are opportunistic omnivores in alpine streams (Zah, Burgherr, Bernasconi, \& Uehlinger, 2001; Füreder, Welter, \& Jackson, 2003; Clitherow, Carrivick, \& Brown, 2013; Di Cugno \& Robinson, 2017; Niedrist \& Füreder, 2017, 2018). It should be noted, though, that a large number of chironomid species are found in alpine waters (e.g., Lods Crozet, Oertli, \& Robinson, 2012). They have extremely flexible feeding strategies that explain their abundance and predominance in glacier-fed streams (Niedrist \& Füreder, 2018). Thus, a more intensive higher resolution analysis of alpine chironomid assemblages and their feeding preferences would help confirm our findings that chironomids are opportunistic omnivores.

Narrower niche widths of Baetidae and Heptageniidae at proglacial, tributary and main channels sites relative to lake outlet sites suggest that these taxa have more specialized diets (Füreder, Welter, \& Jackson, 2003; Niedrist \& Füreder, 2017). This specialization in foraging behaviour may explain the 
presence and absence of these taxa across specific sites as well. For example, the heptageniids found at some sites in all seasons were Ecdyonurus spp. (grazer, detritivore) and Rhithrogena spp. (primarily grazer). Both taxa occurred at sites P, L1, L2 and M2, but they were absent at site T1. Rhithrogena spp. was the only heptageniid present at sites T2 and M1. Thus, spatial patchiness in species distribution and organic resources might have influenced estimated niche widths across streams (also see Clitherow,

413 Carrivick, \& Brown, 2013). As such, we suggest caution regarding interpretations of feeding niches

414 because some of our consumers (including generalist groupings) may comprise different species at each 415 site, of which some may actually be specialists that exploit distinct resources (see Syväranta \& Jones, 2008). However, the wider feeding niches (i.e., more "plastic" feeding behaviour) of Chironomidae in contrast to the narrower niches of Baetidae and Heptageniidae we observed may indicate that the Chironomidae could become "winners", and the latter groups "losers" of ongoing environmental change following glacial retreat. This could be particularly pronounced if glacial retreat shifts alpine stream macroinvertebrate community composition towards chironomid dominance (Milner, Brown, \& Hannah,

$4212009)$.

Lastly, although $\mathrm{SEA}_{\mathrm{c}}$ and $\mathrm{SEA}_{\mathrm{b}}$ performs well in correcting for small sample sizes (Jackson, Parnell, Inger, \& Bearhop, 2011), estimates can still be biased by low measurements, particularly if the population data is skewed and highly variable (Syväranta et al., 2013). Furthermore, niche estimations of all consumers likely represented a mixture of consumer taxa, but we assumed that all species had similar trophic fractionation values, since we did not have auxiliary data available to consider trophic

427 fractionation values for individual species. Carbon and nitrogen trophic fractionation values can vary

428 among and within consumer species (Boecklen, Yarnes, Cook, \& James, 2011). If trophic discrimination varied widely among consumers, this could have either expanded or contracted the niche space estimates

430 for specific sites or seasonal data. Moreover, variance in individual growth rates will enhance 431 uncertainty in niche estimation (Gorokhova, 2018). 

corresponded well to those measured by Zah, Burgherr, Bernasconi, \& Uehlinger (2001) almost two decades ago. The earlier $\delta^{13} \mathrm{C}$ values for macroinvertebrates at sites L1, T1, M1 and M2 ranged from ca. -34 to $-22 \%$, whereas $\delta^{15} \mathrm{~N}$ values ranged from ca. -5 to $6 \%$. In contrast, ranges in macroinvertebrate isotope values measured at 32 non-glacial (krenal/rhithral) streams across 4 glacierized Swiss alpine catchments were lower $\left(\delta^{13} \mathrm{C}\right.$ : -27.9 to $-22.2 \%$; $\delta^{15} \mathrm{~N}$ : -3.5 to $2.5 \%$ ) (Di Cugno \& Robinson, 2017). The findings of Di Cugno \& Robinson (2017) suggest that the feeding niches of macroinvertebrate consumers in alpine streams could become narrower as glaciers continue to retreat and glacier meltwater eventually ceases. suggesting that autochthonous resources were a primary energy source for most macroinvertebrates during most seasons. The same was observed in the previous (1997/1998) study in the Val Roseg catchment by Zah, Burgherr, Bernasconi, \& Uehlinger (2001), who found this reasonable, as aquatic macroinvertebrates in the study streams are primarily grazers and collector gatherers relying on instream sources of organic matter such as periphyton. On the other hand, the variations in consumer $\delta^{15} \mathrm{~N}$ values are affected by variation in $\delta^{15} \mathrm{~N}$ values of basal resources (Peipoch, Martí, \& Gacia, 2012 and references therein) and potential changes in trophic positon of the consumers (Post, 2002). For example, a potential for cannibalism among some taxa (e.g., Diamesinae) drive $\delta^{15} \mathrm{~N}$ variability and also might have contributed to the relatively wide range of chironomid $\delta^{15} \mathrm{~N}$ values at lake outlet sites (e.g.,

453 Peipoch, Martí, \& Gacia, 2012; Niedrist \& Füreder, 2018). The small difference in ranges of isotope 454 values between our data and the earlier findings (Zah, Burgherr, Bernasconi, \& Uehlinger, 2001), were 455 likely due to the new site additions (L2, P and T2) in the present study. Nonetheless, our data on the carbon and nitrogen isotope composition of available basal resources and consumers indicate that the heterogeneity in the stream network and a gradient of glacier meltwater influence is still evident in the 458 study system, similar to the pattern recorded almost two decades ago (Zah, Burgherr, Bernasconi, \& 459 Uehlinger, 2001). Furthermore, the corroboration of the previous findings suggest that the basal resources within the Val Roseg have remained relatively stable despite environmental and biodiversity 
changes (e.g., steepening thermal gradients, upward shifts of stream biota; Finn, Räsänen, \& Robinson, 2010 ) brought on by rapid glacial retreat over the last 20 years. inputs (P-PO ${ }^{3-}, \mathrm{TIC}$, conductivity, turbidity), $\delta^{13} \mathrm{C}$ and $\delta^{15} \mathrm{~N}$ values, and isotope niche estimates support previous findings that glacier meltwater dynamics play an important role in shaping the landscape heterogeneity and energy base within alpine stream ecosystems. Our findings add to existing research by identifying trophic niche widths across the different stream types. Estimated niche widths of all macroinvertebrate consumers and common taxa (Chironomidae, Baetidae, Heptageniidae) varied to some degree in streams having sparse riparian vegetation and were directly influenced by glacier meltwater, but the feeding niche differences across streams and taxa were not significant. This result suggests that macroinvertebrates inhabiting the Val Roseg stream network currently show omnivory, which is likely how consumers adapt to changes in resource availability occurring during ongoing environmental change (i.e., rapid glacial retreat 1-2 km between years 1997-2014). Based on our results coupled with recent findings from Swiss Alpine non-glacial streams (Di Cugno \& Robinson, 2017), we predict that further glacier recession (and a potential cessation of glacier meltwater inflow) will eventually result in narrowing feeding niches (i.e., feeding specialization) of macroinvertebrates inhabiting those streams (see Siebers, Paillex, \& Robinson, 2019). Furthermore, once glacier meltwater ceases, alpine streams could reach a certain "tipping point" due to a major change in alpine stream

479 hydrology and community structure, and basal resources (primarily periphyton) might become 480 insufficient to meet consumer demands (cf. Khamis et al., 2014a). In such scenarios, alpine stream macroinvertebrates that preferentially feed on autochthonous basal resources (i.e., grazers) could potentially become "losers" to ongoing glacial retreat.

\section{Acknowledgments}

We thank AUA laboratory at Eawag for water chemistry analysis. Special thanks to Serge 
providing access to the study area. This research was partially supported by a Swiss Government

489 Excellence Scholarship for Foreign Scholars and Artists (awarded by FCS, Swiss Federal Commission 490 for Scholarships for Foreign Students) to MSP.

\section{Conflict of Interest}

None of the authors declare any conflict of interest.

\section{Data Availability Statement}

The authors confirm that the data supporting the findings of this study are available in the Dryad Digital

Repository (https://doi.org/10.5061/dryad.j3tx95xbj).

\section{References}

500

501

502

503

504

505

506

507

508

509

510

Aigner, S., Herburger, K., Holzinger, A., \& Karsten, U. (2018). Epilithic Chamaesiphon (Synechococcales, Cyanobacteria) species in mountain streams of the Alps - interspecific differences in photo-physiological traits. Journal of Applied Phycology, 30, 1125-1134.

Beniston, M. (2003). Climatic change in mountain regions: a review of possible impacts. Climatic Change, 59, 5-31.

Beniston, M., \& Stoffel, M. (2016). Rain-on-snow events, floods and climate change in the Alps: Events may increase with warming up to $4{ }^{\circ} \mathrm{C}$ and decrease thereafter. Science of the Total Environment, 571, 228-236.

Boecklen, W. J., Yarnes, C. T., Cook, B. A., \& James, A. C. (2011). On the use of stable isotopes in trophic ecology. Annual Review of Ecology, Evolution, and Systematics, 42, 411-440.

Boon, P. I., \& Bunn, S. E. (1994). Variations in the stable isotope composition of aquatic plants and their implications for food web analysis. Aquatic Botany, 48, 99-108.

Brighenti, S., Tolotti, M., Bruno, M. C., Wharton, G., Pusch, M. T., \& Bertoldi, W. (2019). Ecosystem shifts in Alpine streams under glacier retreat and rock glacier thaw: A review. Science of the Total Environment, 675, 542-559.

Burgherr, P., \& Ward, J. V. (2001). Longitudinal and seasonal distribution patterns of the benthic fauna of an alpine glacial stream (Val Roseg, Swiss Alps). Freshwater Biology, 46, 1705-1721. 
Burpee, B. T., Anderson, D., \& Saros, J. E. (2018). Assessing ecological effects of glacial meltwater on lakes fed by the Greenland Ice Sheet: The role of nutrient subsidies and turbidity. Arctic, Antarctic, and Alpine Research, 50, 1. DOI: 10.1080/15230430.2017.1420953

Cauvy-Fraunié, S., Andino, P., Espinosa, R., Calvez, R., Anthelme, F., Jacobsen, D., \& Dangles, O. (2014). Glacial flood pulse effects on benthic fauna in equatorial high-Andean streams. Hydrological Processes, 28, 3008-3017.

Cauvy-Fraunié, S., Espinosa, R., Andino, P., Jacobsen, D., \& Dangles, O. (2015). Invertebrate metacommunity structure and dynamics in an Andean glacial stream network facing climate change. PLoS ONE, 10, e0136793. DOI: https://doi.org/10.1371/journal.pone.0136793

Clitherow, L. R., Carrivick, J. L., \& Brown, L. E. (2013). Food web structure in a harsh glacier-fed river. PLoS ONE, 8, e60899. DOI: https://doi.org/10.1371/journal.pone.0060899

Cutting, K. A., Cross, W. F., Anderson, M. L., \& Reese, E. G. (2016). Seasonal change in trophic niche of adfluvial arctic grayling (Thymallus arcticus) and coexisting fishes in a high-elevation lake system. PLoS ONE, 11, e0156187. DOI: https://doi.org/10.1371/journal.pone.0156187

Di Cugno, N., \& Robinson, C. T. (2017). Trophic structure of macroinvertebrates in alpine non-glacial streams. Fundamental and Applied Limnology, 190, 319-330.

Domisch, S., Jähnig, S. C., \& Haase, P. (2011). Climate-change winners and losers: stream macroinvertebrates of a submontane region in Central Europe. Freshwater Biology, 56, 20092020.

Donlan, R. M. (2002). Biofilms: microbial life on surfaces. Emerging Infectious Diseases, 8, 881-890.

Dudgeon, D. (2010). Prospects for sustaining freshwater biodiversity in the 21 st century: linking ecosystem structure and function. Current Opinion in Environmental Sustainability, 2, 422-430.

Finlay, J. C., \& Kendall, C. (2007). Stable isotope tracing of temporal and spatial variability in organic matter sources to freshwater ecosystems. In R. H. Michener \& K. Lajtha (Eds.), Stable isotopes in ecology and environmental science, 2nd ed. (pp. 283-333). Blackwell Publishing Ltd.

Finlay, J. C., Power, M. E., \& Cabana, G. (1999). Effects of water velocity on algal carbon isotope ratios: implications for river food web studies. Limnology and Oceanography, 44, 1198-1203.

Finn, D. S., Räsänen, K., \& Robinson, C. T. (2010). Physical and biological changes to a lengthening stream gradient following a decade of rapid glacial recession. Global Change Biology, 16, 3314-3326.

Flemming, H.-C., Wingender, J. G., \& Mayer, C. (2000). Physico-chemical properties of biofilms, In L. V. Evans (Ed.), Biofilms: recent advances in their study and control (pp. 19-34). Amsterdam: Harwood Academic Publishers.

Fort, H., \& Segura, A. (2017). Competition across diverse taxa: quantitative integration of theory and empirical research using global indices of competition. Oikos, 127, 392-402. 
Füreder, L. (1999). High alpine streams: cold habitats for insect larvae. Cold adapted organisms. In R. Margesin \& F. Schinner (Eds.), Ecology, physiology, enzymology and molecular biology (pp. 181-196). Berlin and Heidelberg: Springer Verlag.

Füreder, L., Schütz, C., Wallinger, M., \& Burger, R. (2001). Physico-chemistry and aquatic insects of a glacier-fed and a spring-fed alpine stream. Freshwater Biology, 46, 1673-1690.

Füreder, L., Welter, C., \& Jackson, J. K. (2003). Dietary and stable isotope $\left(\delta^{13} \mathrm{C}, \delta^{15} \mathrm{~N}\right)$ analyses in alpine stream insects. International Review of Hydrobiology, 88, 314-331.

Gibson, J. J., \& Prowse, T. D. (2002). Stable isotopes in river ice: identifying primary over-winter streamflow signals and their hydrological significance. Hydrological Processes, 16, 873-890.

Giersch, J. J., Hotaling, S., Kovach, R. P., Jones, L. A., \& Muhlfeld, C. C. (2017). Climate-induced glacier and snow loss imperils alpine stream insects. Global Change Biology, 23, 2577-2589.

Gorokhova, E. (2018). Individual growth as a non-dietary determinant of the isotopic niche metrics. Methods in Ecology and Evolution, 9, 269-277.

Handley, L. L., \& Raven, J. A. (1992). The use of natural abundance of nitrogen isotopes in plant physiology and ecology. Plant, Cell \& Environment, 15, 965-985.

Hayden, B., Harrod, C., \& Kahilainen, K. K. (2014). Dual fuels: intra-annual variation in the relative importance of benthic and pelagic resources to maintenance, growth and reproduction in a generalist salmonid fish. Journal of Animal Ecology, 83, 1501-1512.

Helland, I. P., Finstad, A. G., Forseth, T., Hesthagen, T., \& Ugedal, O. (2011). Ice-cover effects on competitive interactions between two fish species. Journal of Animal Ecology, 80, 539-547.

Hieber, M., Robinson, C. T., Uehlinger, U., \& Ward, J. V. (2002). Are alpine lake outlets less harsh than other alpine streams? Archiv für Hydrobiologie, 154, 199-223.

Hill, W. R., \& Middleton, R. G. (2006). Changes in carbon stable isotope ratios during periphyton development. Limnology and Oceanography, 51, 2360-2369.

Holten, J. I., \& Carey, P. D. (1992). Responses of climate change on natural terrestrial ecosystems in Norway. NINA Institute Research Report, 29, 1-59.

Hotaling, S., Finn, D. S., Giersch, J. J., Weisrock, D. W., \& Jacobsen, D. (2017). Climate change and alpine stream biology: progress, challenges, and opportunities for the future. Biological Reviews, 92, 2024-2045.

Huss, M. (2012). Extrapolating glacier mass balance to the mountain-range scale: The European Alps 1900-2100. Cryosphere, 6, 713-727.

Huss, M., Bookhagen, B., Huggel, C., Jacobsen, D., Bradley, R. S., Clague, J. J., ... Winder, M. (2017). Toward mountains without permanent snow and ice. Earth's Future, 5, 418-435.

IPCC (2014). Climate change 2014: Synthesis report. Cambridge and New York: Cambridge University Press. 
Jackson, A. L., Parnell, A. C., Inger, R., \& Bearhop, S. (2011). Comparing isotopic niche widths among and within communities: SIBER - Stable Isotope Bayesian Ellipses in R. Journal of Animal Ecology, 80, 595-602.

Jantze, E. J., Laudon, H., Dahlke, H. E., \& Lyon, S. W. (2015). Spatial variability of dissolved organic and inorganic carbon in subarctic headwater streams. Arctic, Antarctic, and Alpine Research, 47, $529-546$.

Khamis, K., Hannah, D. M., Brown, L. E., Tiberti, R., \& Milner, A. M. (2014a). The use of invertebrates as indicators of environmental change in alpine rivers and lakes. Science of the Total Environment, 493, 1242-54.

Khamis, K., Hannah, D. M., Hill, M., Brown, L. E., Castella, E., \& Milner, A. M. (2014b). Alpine aquatic ecosystem conservation policy in a changing climate. Environmental Science \& Policy, $43,39-55$.

Lancaster, J., \& Waldron, S. (2001). Stable isotope values of lotic invertebrates: Sources of variation, experimental design, and statistical interpretation. Limnology and Oceanography, 46, 723-730.

Layman, C. A., \& Allgeier, J. E. (2012). Characterizing trophic ecology of generalist consumers: a case study of the invasive lionfish in The Bahamas. Marine Ecology Progress Series, 448, 131-141.

Layman, C. A., Arrington, D. A., Montaña, C. G., \& Post, D. M. (2007). Can stable isotope ratios provide for community-wide measures of trophic structure? Ecology, 88, 42-48.

Lods-Crozet, B., Oertli, B., \& Robinson, C. T. (2012). Long-term patterns of chironomid assemblages in a high elevation stream/lake network (Switzerland) - Implications to global change. Fauna Norvegica, 31, 71-85.

Malard, F., Tockner, K., \& Ward, J. V. (1999). Shifting dominance of subcatchment water sources and flow paths in a glacial floodplain, Val Roseg, Switzerland. Arctic, Antarctic, and Alpine Research, 31, 135-150.

McConnaughey, T., \& McRoy, C. P. (1979). Food-web structure and the fractionation of carbon isotopes in the Bering Sea. Marine Biology, 53, 257-262.

McKernan, C., Cooper, D. J., \& Schweiger, E. W. (2018). Glacial loss and its effect on riparian vegetation of alpine streams. Freshwater Biology, 63, 518-529.

Milner, A. M., Brittain, J. E., Castella, E., \& Petts, G. E. (2001). Trends of macroinvertebrate community structure in glacier-fed rivers in relation to environmental conditions: a synthesis. Freshwater Biology, 46, 1833-1847.

Milner, A. M., Brown, L. E., \& Hannah, D. M. (2009). Hydroecological response of river systems to shrinking glaciers. Hydrological Processes, 23, 62-77.

Milner, A. M., Khamis, K., Battin, T. J., Brittain, J. E., Barrand, N. E., Füreder, L., .. Brown, L. E. (2017). Glacier shrinkage driving global changes in downstream systems. PNAS, 114, 97709778. 
Niedrist, G. H., \& Füreder, L. (2016). Towards a definition of environmental niches in alpine streams by employing chironomid species preferences. Hydrobiologia, 781, 143-160.

Niedrist, G. H., \& Füreder, L. (2017). Trophic ecology of alpine stream invertebrates: current status and futurre research needs. Freshwater Science, 36, 466-478.

Niedrist, G. H., \& Füreder, L. (2018). When the going gets tough, the tough get going: the enigma of survival strategies in harsh glacial stream environments. Freshwater Biology, 63, 1260-1272.

Nielsen, J. M., Clare, E. L., Hayden, B., Brett, M. T., Kratina, P. (2018). Diet tracing in ecology: Method comparison and selection. Methods in Ecology and Evolution, 9, 278- 291.

Nowak, M. E., Schwab, V. F., Lazar, C. S., Behrendt, T., Kohlhepp, B., Totsche, K. U., ... Trumbore, S. E. (2017). Carbon isotopes of dissolved inorganic carbon reflect utilization of different carbon sources by microbial communities in two limestone aquifer assemblages. Hydrology and Earth System Sciences, 21, 4283-4300.

Opdam, P., \& Wascher, D. (2004). Climate change meets habitat fragmentation: linking landscape and biogeographical scale levels in research and conservation. Biological Conservation, 117, 285297.

Peipoch, M., Martí, E., \& Gacia, E. (2012). Variability in $\delta^{15} \mathrm{~N}$ natural abundance of basal resources in fluvial ecosystems: a meta-analysis. Freshwater Science, 31, 1003-1015.

Post, D. M. (2002). Using stable isotopes to estimate trophic position: models, methods, and assumptions. Ecology, 83, 703-718.

Robinson, C. T., Schmid, D., Svoboda, M., \& Bernasconi, S. M. (2008). Functional measures and food webs of high elevation springs in the Swiss alps. Aquatic Sciences, 70, 432-445.

Robinson, C.T., Tonolla, D., Imhof, B., Vukelic, R., \& Uehlinger, U. (2016). Flow intermittency, physico-chemistry and function of headwater streams in an Alpine glacial catchment. Aquatic Sciences, 78, 327-341.

Rott, E., Cantonati, M., Füreder, L., \& Pfister, P. (2006). Benthic algae in high altitude streams of the alps - a neglected component of the aquatic biota. Hydrobiologia, 562, 195-216.

Roy, J. W., Zaitlin, B., Hayashi, M., \& Watson, S. B. (2011). Influence of groundwater spring discharge on small-scale spatial variation of an alpine stream ecosystem. Ecohydrology, 4, 661-670.

Sauro, J., \& Lewis, J. R. (2016). Quantifying the user experience: practical statistics for user research (2nd ed.). Cambridge: Elsevier Inc.

Scheffer, M., Bascompte, J., Brock, W. A., Brovkin, V., Carpenter, S. R., Dakos, V., ... Sugihara, G. (2009). Early-warning signals for critical transitions. Nature, 461, 53-59.

Sertić Perić, M., Jolidon, C., Uehlinger, U., \& Robinson, C. T. (2015). Long-term ecological patterns of alpine streams: an imprint of glacial legacies. Limnology and Oceanography, 60, 992-1007.

Sertić Perić, M., \& Robinson, C. T. (2015). Spatio-temporal shifts of macroinvertebrate drift and benthos in headwaters of a retreating glacier. Hydrobiologia, 751, 25-41. 
Shugar, D. H., Calgue, J. J., Best, J. L., Schoof, C., Willis, M. J., Copland, L., \& Roe, G. H. (2017). River piracy and drainage basin reorganization led by climate-driven glacier retreat. Nature Geoscience, 10, 370-375.

Siebers, A. R., Paillex, A., \& Robinson, C. T. (2019). Flow intermittency influences the trophic base, but not the overall diversity of alpine stream food webs. Ecography, 42, 1523-1535.

Slemmons, K. E. H., Saros, J. E., \& Simon, K. (2013). The influence of glacial meltwater on alpine aquatic ecosystems: a review. Environmental Science: Processes \& Impacts, 15, 1794-1806.

Sokal, R. R., \& Rohlf, F. J. (1995). Biometry: The principles and practice of statistics in biological research (3rd ed.). New York: W. H. Freeman.

StatSoft, Inc. (2010). STATISTICA (data analysis software system), version 9.1. Available from www.statsoft.com.

Syväranta, J., \& Jones, R. I. (2008). Changes in feeding niche widths of perch and roach following biomanipulation, revealed by stableisotope analysis. Freshwater Biology, 53, 425-434.

Syväranta, J., Lensu, A., Marjomäki, T. J., Oksanen, S., \& Jones, R. I. (2013). An empirical evaluation of the utility of convex hull and standard ellipse areas for assessing population niche widths from stable isotope data. PloS ONE, 8, e56094. DOI: https://doi.org/10.1371/journal.pone.0056094

Tachet, H., Richoux, P., Bournard, M., \& Usseglio-Polatera, P. (2010). Invertébrés d'eau douce: Systématique, biologie, écologie. Paris: CNRS Éditions.

Tockner, K., Malard, F., Burgherr, P., Robinson, C. T., Uehlinger, U., Zah, R., \& Ward, J. V. (1997). Physico-chemical characterization of channel types in a glacial floodplain ecosystem (Val Roseg, Switzerland). Archiv für Hydrobiologie, 140, 433-463.

Uehlinger, U., Robinson, C. T., Hieber, M., \& Zah, R. (2010). The physico-chemical habitat template for periphyton in alpine glacial streams under a changing climate. Hydrobiologia, 657, 107-121.

Ward, J. V. (1994). Ecology of alpine streams. Freshwater Biology, 32, 277-294.

Ward, J. V., \& Uehlinger, U. (2003). Ecology of a glacial flood plain. Dordrecht and London: Kluwer Academic Publishers.

Wookey, P. A., Aerts, R., Bardgett, R. D., Baptist, F., Brathen, K. A., Cornelissen, J. H. C., .. Shaver, G. R. (2009). Ecosystem feedbacks and cascade processes: understanding their role in the responses of Arctic and alpine ecosystems to environmental change. Global Change Biology, $15,1153-1172$.

Wu, Y. (2016). Periphyton: functions and application in environmental remediation. Amsterdam, Oxford and Cambridge: Elsevier.

Zah, R., Burgherr, P., Bernasconi, S. M., \& Uehlinger, U. (2000). Contribution of organic resources to a glacial stream (Val Roseg, Swiss Alps) — a stable isotope study. SIL Proceedings, 1922-2010, 27:3, 1635-1639. DOI: 10.1080/03680770.1998.11901516 
695 Zah, R., Burgherr, P., Bernasconi, S. M., \& Uehlinger, U. (2001). Stable isotope analysis of

696 macroinvertebrates and their food sources in a glacier stream. Freshwater Biology, 46, 871-882.

697 Zah, R., Niederöst, M., Rinderpacher, H., \& Uehlinger, U. (2001). Long-term dynamics of the channel

698 network in a glacial floodplain, Val Roseg, Switzerland. Arctic, Antarctic, and Alpine Research, $699 \quad 33,440-446$.

700 Zemp, M., Haeberli, W., Hoelzle, M., \& Paul, F. (2006). Alpine glaciers to disappear within decades?

$701 \quad$ Geophysical Research Letters, 33, L13504.

702 Zemp, M., Huss, M., Thibert, E., Eckert, N., McNabb, R., Huber, J., ... Cogley, J. G. (2019). Global

703 glacier mass changes and their contributions to sea-level rise from 1961 to 2016. Nature, 568, 382-386. 
Table 2. Physical, chemical and macroinvertebrate taxa richness at sites measured during the study period (November 2013 - July 2014). SE $=$ standard error; $713 \mathrm{CV}=$ coefficient of variation (expressed in percent, \%); MIN = minimal value; MAX = maximal value ( $\mathrm{n}=4$ for L1, T1, M1 and M2; $\mathrm{n}=3$ for L2, $\mathrm{P}, \mathrm{T} 2)$.

714 Parameter notations are in material and methods.

\begin{tabular}{|c|c|c|c|c|c|c|c|c|c|c|}
\hline & & \multicolumn{2}{|c|}{ Physical } & \multicolumn{6}{|c|}{ Chemical } & \multirow{2}{*}{$\begin{array}{c}\text { Biological } \\
\text { Taxa richness } \\
\text { (Number of taxa) }\end{array}$} \\
\hline Site & & $\begin{array}{c}\text { Water } \\
\text { temperature } \\
{\left[{ }^{\circ} \mathrm{C}\right]} \\
\end{array}$ & $\begin{array}{c}\text { Turbidity } \\
\text { [NTU] } \\
\end{array}$ & $\begin{array}{l}\text { Conductivity } \\
{\left[\mu \mathrm{S} \mathrm{cm}^{-1}\right]} \\
\end{array}$ & $\begin{array}{c}\mathrm{DOC} \\
{\left[\mathrm{mg} \mathrm{C} \mathrm{L}^{-1}\right]} \\
\end{array}$ & $\begin{array}{c}\text { TOC } \\
{\left[\mathrm{mg} \mathrm{C} \mathrm{L}^{-1}\right]} \\
\end{array}$ & $\begin{array}{c}\text { TIC } \\
{\left[\mathrm{mg} \mathrm{C} \mathrm{L}^{-1}\right]} \\
\end{array}$ & $\begin{array}{c}\mathrm{NO}_{3}{ }^{-}-\mathrm{N} \\
{\left[\mathrm{mg} \mathrm{N} \mathrm{L}^{-1}\right]} \\
\end{array}$ & $\begin{array}{c}\mathrm{PO}_{4}{ }^{3--} \mathrm{P} \\
{\left[\mu \mathrm{g} \mathrm{P} \mathrm{L}^{-1}\right]} \\
\end{array}$ & \\
\hline \multirow{4}{*}{$\mathbf{L 1}$} & MEAN & 3.6 & 31.9 & 53.1 & 0.54 & 0.67 & 5.40 & $<0.25$ & 1.28 & 3.8 \\
\hline & $\mathrm{SE}$ & 2.3 & 14.5 & 4.2 & 0.03 & 0.07 & 0.26 & \multirow{3}{*}{ NA } & 0.15 & 1.0 \\
\hline & $\mathrm{CV}(\%)$ & 129 & 91 & 16 & 13 & 20 & 10 & & 24 & 55 \\
\hline & MIN - MAX & $0.2-10.5$ & $6.4-68.9$ & $43.7-64.1$ & $0.50-0.64$ & $0.50-0.79$ & $4.72-5.97$ & & $1.00-1.70$ & $1-6$ \\
\hline \multirow{4}{*}{$\mathbf{L} 2$} & MEAN & 5.5 & 27.2 & 55.4 & 0.65 & 0.58 & 5.79 & $<0.25$ & 1.05 & 7.7 \\
\hline & SE & 2.9 & 9.9 & 1.2 & 0.01 & 0.07 & 0.33 & \multirow{3}{*}{ NA } & 0.05 & 1.2 \\
\hline & $\mathrm{CV}(\%)$ & 92 & 63 & 4 & 3 & 17 & 8 & & 7 & 27 \\
\hline & MIN - MAX & $2.5-11.3$ & $7.69-40.2$ & $53.1-57.3$ & $0.64-0.67$ & $0.51-0.65$ & $5.45-6.12$ & & $1.00-1.10$ & $6-10$ \\
\hline \multirow{4}{*}{$\mathbf{P}$} & MEAN & 2.9 & 76.7 & 71.9 & 0.56 & 0.63 & 6.76 & 0.26 & 3.93 & 3.7 \\
\hline & SE & 0.9 & 63.9 & 19.8 & 0.06 & 0.02 & 1.03 & 0.01 & 0.52 & 0.3 \\
\hline & $\mathrm{CV}(\%)$ & 56 & 144 & 48 & 18 & 6 & 26 & 6 & 23 & 16 \\
\hline & MIN - MAX & $1.1-4.2$ & $3.63-204$ & $37.3-106$ & $0.50-0.67$ & $0.59-0.66$ & $4.87-8.39$ & $0.25-0.28$ & $3.10-4.90$ & $3-4$ \\
\hline \multirow{4}{*}{$\mathbf{T 1}$} & MEAN & 3.6 & 4.9 & 65.0 & 0.75 & 0.77 & 6.89 & 0.29 & 4.20 & 5.3 \\
\hline & SE & 1.0 & 1.6 & 14.7 & 0.11 & 0.14 & 1.29 & 0.02 & 1.20 & 0.3 \\
\hline & $\mathrm{CV}(\%)$ & 53 & 67 & 45 & 29 & 36 & 37 & 16 & 57 & 11 \\
\hline & MIN - MAX & $0.9-5.4$ & $0.9-8.1$ & $38.5-105.6$ & $0.5-1.0$ & $0.5-1.1$ & $5.0-10.6$ & $0.25-0.35$ & $2.20-7.70$ & $5-6$ \\
\hline \multirow{4}{*}{$\mathbf{T} 2$} & MEAN & 5.8 & 2.0 & 38.4 & 0.90 & 0.97 & 4.58 & $<0.25$ & 1.60 & 8.3 \\
\hline & $\mathrm{SE}$ & 1.4 & 0.3 & 3.8 & 0.13 & 0.27 & 0.03 & \multirow{3}{*}{ NA } & 0.15 & 2.0 \\
\hline & $\mathrm{CV}(\%)$ & 43 & 26 & 17 & 24 & 48 & 1 & & 17 & 42 \\
\hline & MIN - MAX & $3.0-7.7$ & $1.6-2.6$ & $31.7-44.8$ & $0.7-1.1$ & $0.6-1.5$ & $4.5-4.6$ & & $1.4-1.90$ & $5-12$ \\
\hline
\end{tabular}




\begin{tabular}{|c|c|c|c|c|c|c|c|c|c|c|}
\hline \multirow{4}{*}{ M1 } & MEAN & 6.1 & 48.2 & 72.8 & 0.53 & 0.71 & 7.57 & $<0.25$ & 1.38 & 7.5 \\
\hline & $\mathrm{SE}$ & 2.3 & 44.1 & 9.6 & 0.03 & 0.13 & 0.86 & \multirow{3}{*}{ NA } & 0.38 & 0.6 \\
\hline & $\mathrm{CV}(\%)$ & 77 & 183 & 26 & 12 & 36 & 23 & & 55 & 17 \\
\hline & MIN - MAX & $2.7-12.7$ & $1.7-180.5$ & $49.4-96.2$ & $0.50-0.63$ & $0.50-1.08$ & $5.38-9.57$ & & $1.00-2.50$ & $6-9$ \\
\hline \multirow{4}{*}{ M2 } & MEAN & 6.4 & 158.2 & 71.6 & 0.62 & 0.73 & 7.03 & 0.25 & 1.18 & 7.0 \\
\hline & SE & 2.6 & 155.9 & 7.2 & 0.07 & 0.14 & 0.55 & 0.00 & 0.09 & 0.0 \\
\hline & $\mathrm{CV}(\%)$ & 81 & 197 & 20 & 22 & 38 & 16 & 3 & 15 & 0 \\
\hline & MIN - MAX & $1.5-12.7$ & $0.7-626.0$ & $54.5-89.4$ & $0.5-0.8$ & $0.5-1.0$ & $5.5-8.2$ & $0.25-0.27$ & $1.00-1.40$ & NA \\
\hline
\end{tabular}


Table 3. Stream macroinvertebrate taxa collected $(\bullet)$ at seven sites in autumn, winter, spring and summer 2013/2014. In winter, sampling was not possible for some sites because they were either 718 inaccessible (L2, P) or dry (T2).

\begin{tabular}{|c|c|c|c|c|c|c|c|c|c|c|c|c|c|c|c|c|c|c|c|c|c|c|c|c|c|c|}
\hline & \multirow[b]{2}{*}{ Taxon } & \multicolumn{7}{|c|}{ Autumn } & \multicolumn{4}{|c|}{ Winter } & \multicolumn{7}{|c|}{ Spring } & \multicolumn{7}{|c|}{ Summer } \\
\hline & & $\mathrm{L} 1$ & $\mathrm{~L} 2$ & $\mathrm{P}$ & $\mathrm{T} 1$ & $\mathrm{~T} 2$ & M1 & $\mathrm{M} 2$ & $\mathrm{~L} 1$ & $\mathrm{~T} 1$ & M1 & $\mathrm{M} 2$ & $\mathrm{~L} 1$ & $\mathrm{~L} 2$ & $\mathrm{P}$ & $\mathrm{T} 1$ & $\mathrm{~T} 2$ & M1 & M2 & $\mathrm{L} 1$ & $\mathrm{~L} 2$ & $\mathrm{P}$ & $\mathrm{T} 1$ & $\mathrm{~T} 2$ & M1 & $\mathrm{M} 2$ \\
\hline Filterer-collector & Simulium spp. & & & & & & & $\cdot$ & & & • & & & & & & • & • & - & • & • & & $\cdot$ & • & • & • \\
\hline \multirow[t]{2}{*}{ Gatherer-collector } & Leuctra spp. & & • & & & & - & & & & & & - & - & & & • & - & & & & & & & & \\
\hline & Rhithrogena spp. & • & $\cdot$ & $\cdot$ & & • & $\cdot$ & $\cdot$ & $\cdot$ & & • & $\cdot$ & • & $\cdot$ & & & • & $\cdot$ & - & & $\cdot$ & • & & • & & \\
\hline \multirow[t]{5}{*}{ Grazer } & Baetis alpinus & & • & $\cdot$ & $\cdot$ & & • & $\cdot$ & - & & - & - & • & • & • & • & • & • & • & & - & - & - & $\cdot$ & • & • \\
\hline & Baetis rhodani & & & & & & & & & & & • & & & & & & & & & & & & & & \\
\hline & Chironomidae & & • & $\cdot$ & $\bullet$ & $\cdot$ & $\cdot$ & $\cdot$ & & & $\cdot$ & & & & $\cdot$ & $\bullet$ & - & • & • & $\bullet$ & • & - & • & $\cdot$ & $\cdot$ & \\
\hline & Ecdyonurus spp. & & & & & & & & • & & & • & - & & & & & & & $\cdot$ & - & - & & & & \\
\hline & Liponeura spp. & & & & & & & & & & & & & & & & & & & & $\cdot$ & & & & - & $\cdot$ \\
\hline \multirow[t]{10}{*}{ Predator } & Crenobia alpina & & & & & $\bullet$ & & & & & & & • & & & & $\bullet$ & & & & • & & • & & & \\
\hline & Hydrachnidia & & & & & & & & & & & & & & & & & & & & & & & & & • \\
\hline & Ceratopogonidae & & & & & & & & & & & & & & • & & • & & & & & & & & & \\
\hline & Dicranota sp. & & & & • & $\cdot$ & $\cdot$ & $\cdot$ & & & $\cdot$ & & & $\cdot$ & & $\cdot$ & • & • & • & & • & & & & • & \\
\hline & Rhypholophus sp. & & & $\cdot$ & & & & & & & & & & & & & & & & & & & & & & \\
\hline & Dictyogenus sp. & & & & $\cdot$ & & & & & & $\cdot$ & $\cdot$ & & & & $\cdot$ & • & & • & & & & & • & & \\
\hline & Isoperla spp. & & • & & & $\cdot$ & & $\cdot$ & $\cdot$ & & & & & & & & & & & & & & $\cdot$ & & & \\
\hline & Siphonoperla sp. & & & & & & & & & & & & & & & & & • & & & • & & & & $\cdot$ & $\bullet$ \\
\hline & Perlodes sp. & & & & & & $\cdot$ & & & & & & & & & & & • & & & & & & & & \\
\hline & Rhyacophila spp. & & $\bullet$ & & & & & $\cdot$ & & & & $\bullet$ & & • & & & • & • & & & • & & & & • & • \\
\hline \multirow[t]{4}{*}{ Shredder } & Capnia sp. & & & & • & • & & & & & & & & & & & & & & & & & & & & \\
\hline & Protonemura spp. & & & & & $\cdot$ & & & & & & & $\cdot$ & - & & & & & & & & & & & & \\
\hline & Rhabdiopteryx sp. & & & & & & & & & & - & & & • & & & - & & & & & & & & & \\
\hline & Limnephilidae & & & & & & & & & & & & & & & $\cdot$ & $\cdot$ & & $\bullet$ & $\bullet$ & & & $\cdot$ & & & \\
\hline
\end{tabular}


721 Figure 1. The location of the Val Roseg floodplain (indicated by square in southeast Switzerland), and 722 enlarged map with location of study sites (modified from Zah et al. 2001a, b). Study sites marked with 723 gray circles were sampled both in 1997/1998 (Zah et al. 2001a, b) and 2013/2014, whereas black circles 724 indicate additional sites included in 2013/2014. Gray lines illustrate the approximate glacial retreat 725 during the last 15 years.

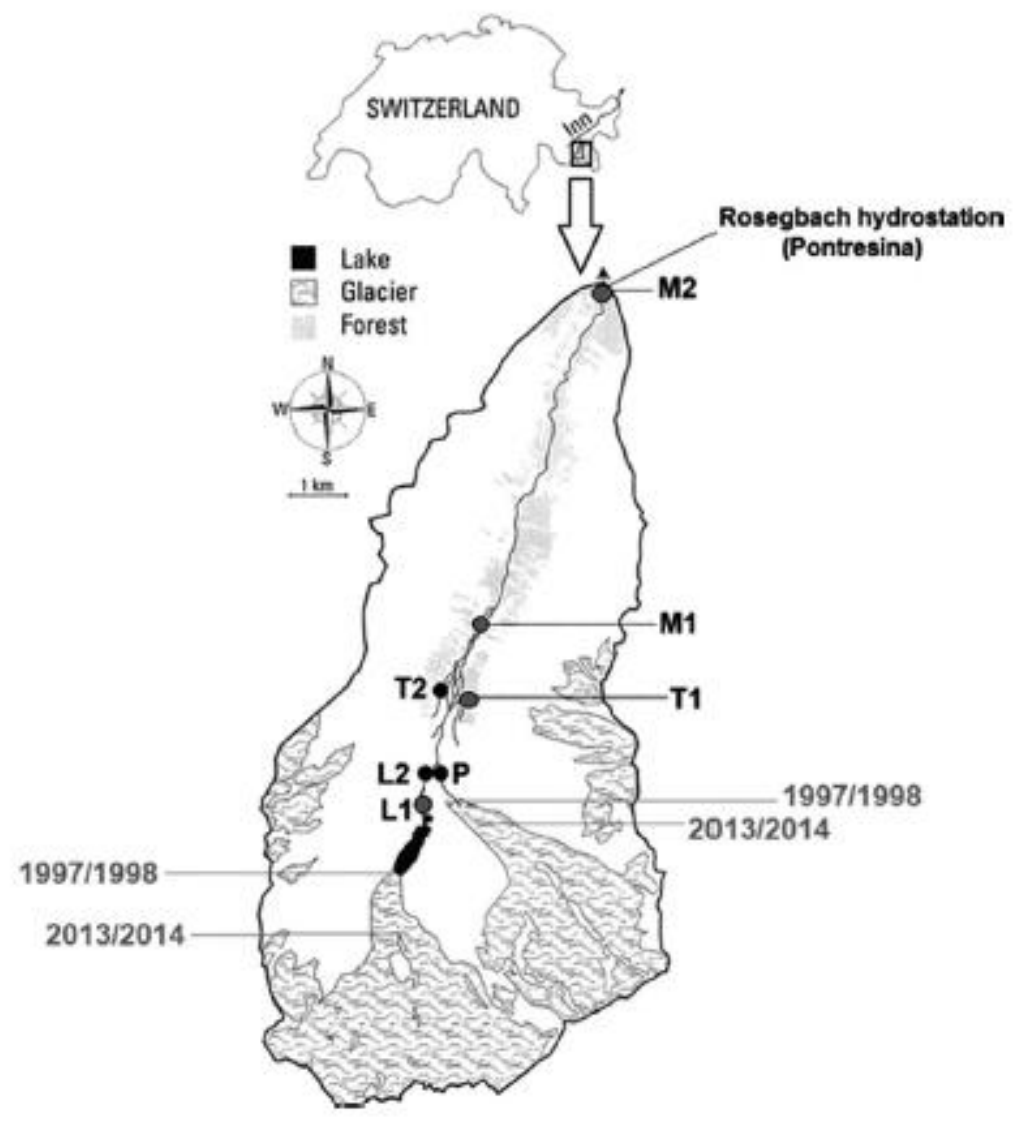

727 Figure 2. PCA ordination (PCA-1 x PCA-2) based on seasonal measurements ( $\mathrm{n}=4$ for L1, T1, M1 and $728 \mathrm{M} 2 ; \mathrm{n}=3$ for L2, $\mathrm{P}, \mathrm{T} 2$ ) of 8 physico-chemical variables measured at each site during the study period.

729 Variable codes are in material and methods. Error bars illustrate temporal variation (SE range) in measured physical-chemical parameters at each study site. 


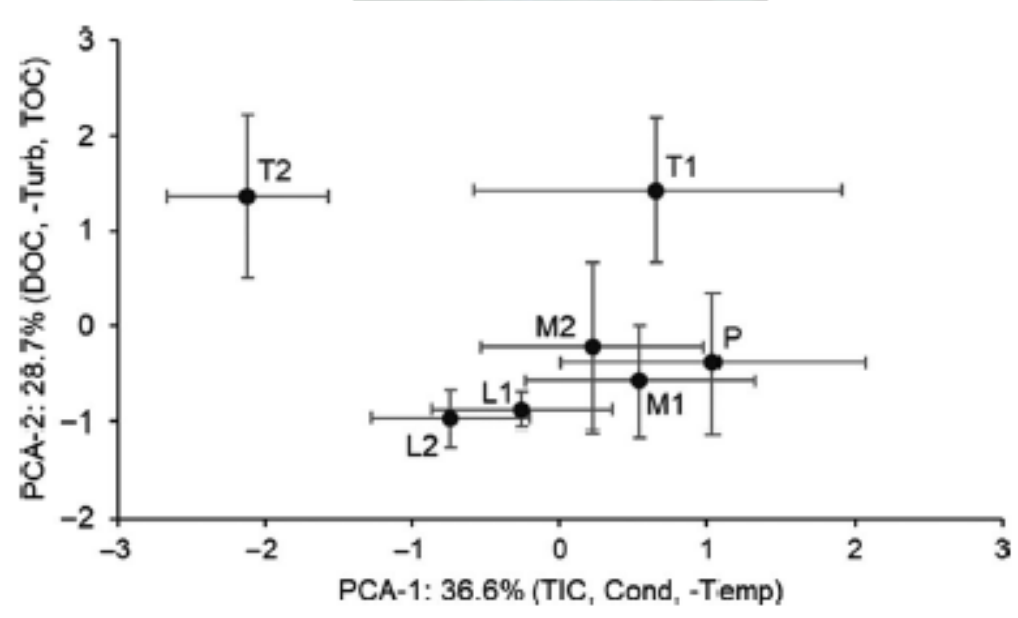

731

732 Figure 3. Differences in resource (periphyton, detritus, riparian vegetation) presence and their mean $( \pm$ $733 \mathrm{SE}) \delta^{13} \mathrm{C}$ and $\delta^{15} \mathrm{~N}$ values across different stream types. Arrows denote significant differences (i.e.,

734 significantly higher vs. lower values) of measured carbon isotope ratios $\left(\delta^{13} \mathrm{C}\right)$ among stream types, as 735 confirmed by a Kruskal-Wallis test and post hoc multiple comparison procedure $(\mathrm{p} \leq 0.05)$. Note that 736 there was no riparian vegetation for the proglacial stream.

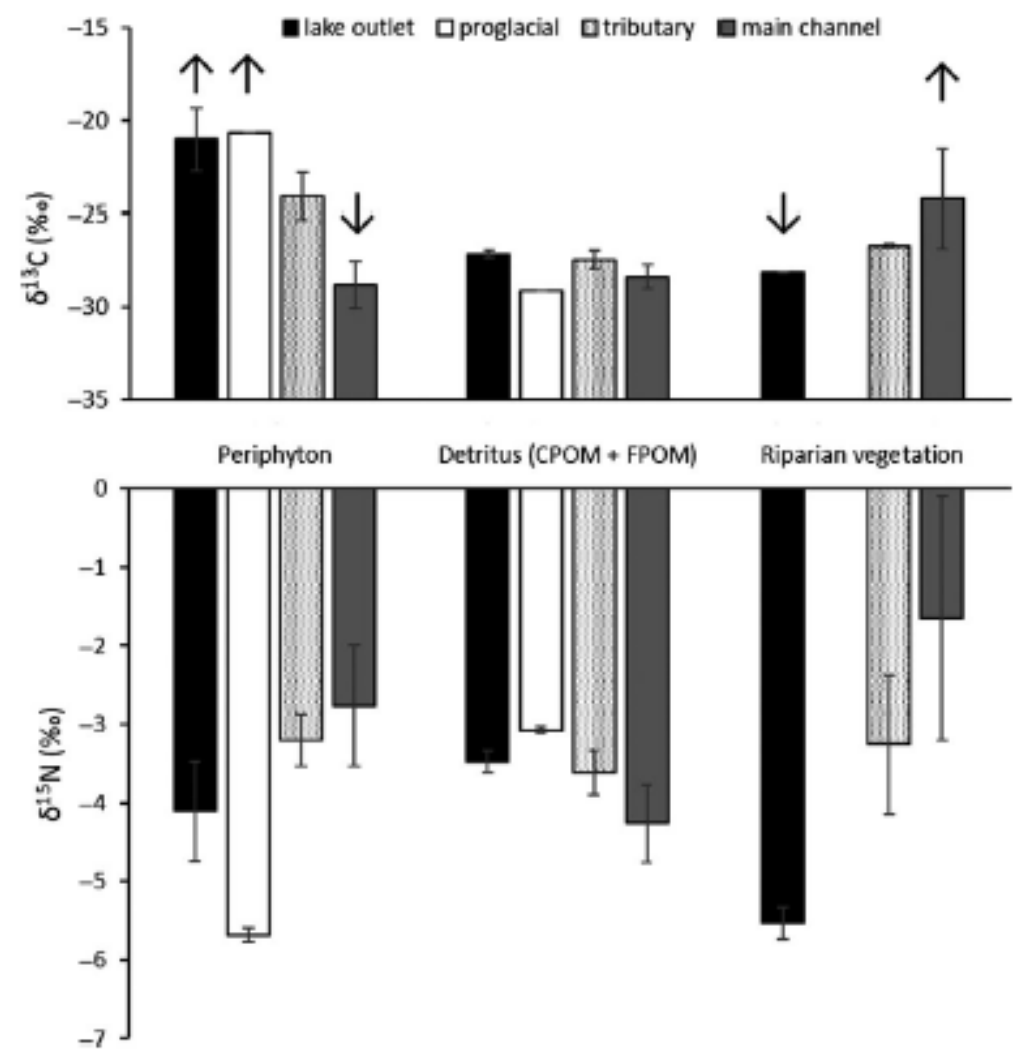


Figure 4. Biplot of $\delta^{13} \mathrm{C}$ and $\delta^{15} \mathrm{~N}$ values and estimated niche widths (circles) for all macroinvertebrate consumers and seasons at each study site (a), and for Chironomidae (b), Baetidae (c) and Heptageniidae (d) for lake outlet, main channel, proglacial and tributary sites. Circles represent 50\% standard ellipse areas of the niche width estimates. The sample size-corrected standard ellipse area estimates $\left(\mathrm{SEA}_{\mathfrak{c}}, \%^{2}{ }^{2}\right)$ are presented in Table $\mathrm{S} 2$. Note scaling differences of $\mathrm{x}$ - and $\mathrm{y}$-axes.
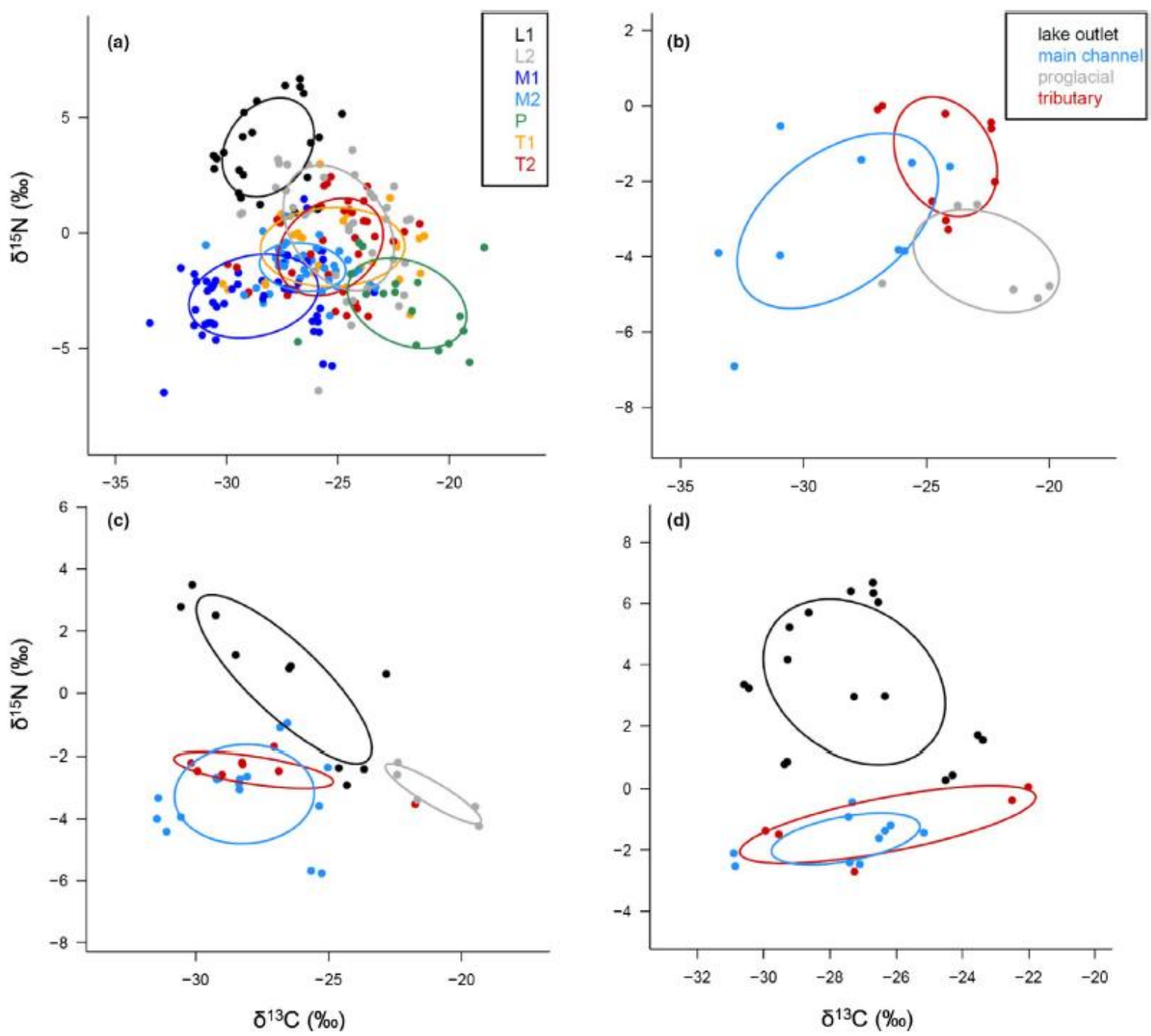

Figure 5. Significant $(\mathrm{p}<0.05)$ relationships between physico-chemical characteristics $\left(\mathrm{P}_{-} \mathrm{PO}_{4}{ }^{3-}\right.$ and $\mathrm{TIC}$

745 concentrations, conductivity, turbidity) and stable isotope ratios $\left(\delta^{13} \mathrm{C}, \delta^{15} \mathrm{~N}\right)$ and isotope niche

746 parameter $\mathrm{SEA}_{\mathrm{c}}$ based on standard correlation analysis. The dashed line depicts the 0.95 confidence interval. For $\delta^{13} \mathrm{C}$ (Fig. 5a) and $\delta^{15} \mathrm{~N}$ (Fig. 5b, c), the dots represent sampling site*season data points $(\mathrm{n}=$

748 24), whereas for $\mathrm{SEA}_{\mathrm{c}}$ (Fig. 5d), the blue dots are available site means across all seasons $(\mathrm{n}=7)$. Site 


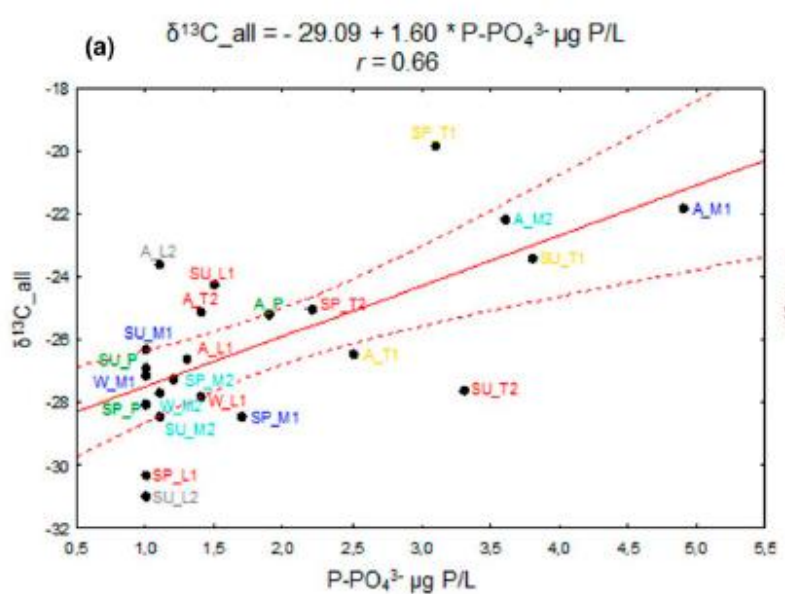

(c) $\delta^{15 \mathrm{~N} \_a l l}=3.28-0.07$ * Conductivity $(\mu \mathrm{S} / \mathrm{cm})$

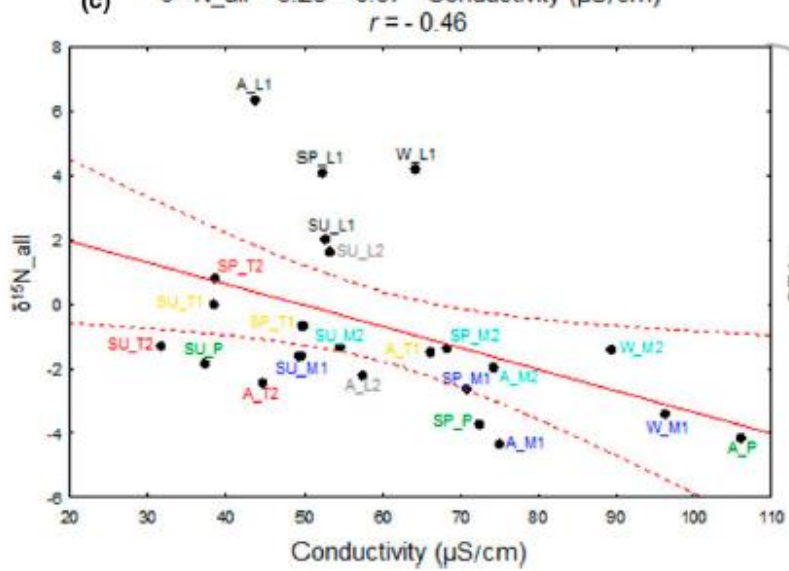

(b) $\quad 0^{15 \mathrm{~N}}$ all $=5.69-1.03 \times \mathrm{TIC} \mathrm{mg} \mathrm{Cl}$

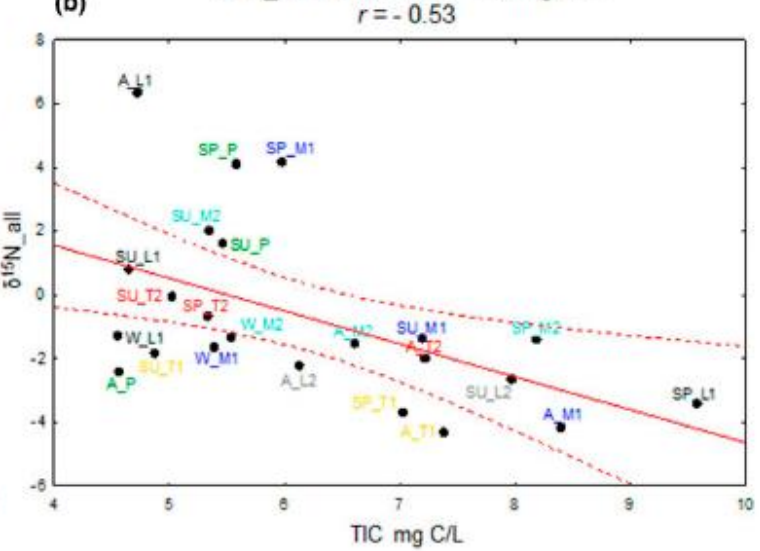

(d) SEAc_all $=13.55-0.05 *$ Turbidity (NFU) $r=-0.80$

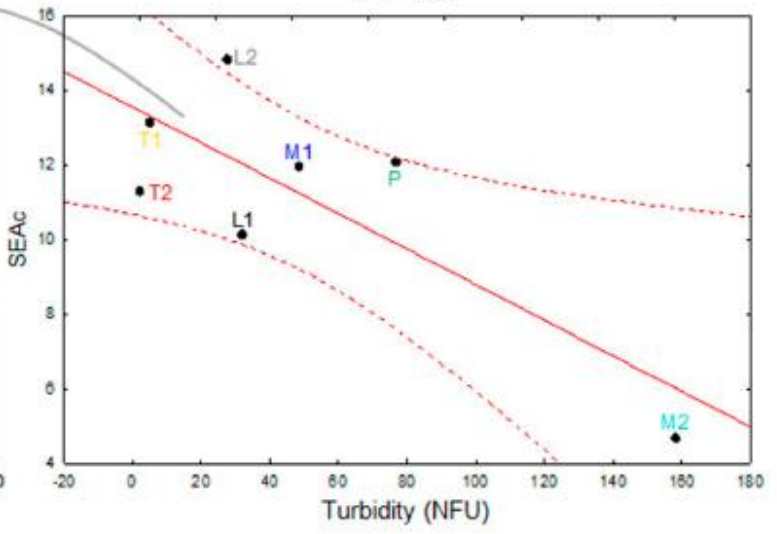

752 Figure 6. Seasonal dynamics in carbon and nitrogen isotopes ( $\delta 13 \mathrm{C}, \delta 15 \mathrm{~N}$; mean $\pm \mathrm{SE}$ ) for potential

753 food sources (periphyton, detritus, riparian vegetation), all aquatic macroinvertebrates, and common macroinvertebrate families (Baetidae, Chironomidae, Heptageniidae) found at the sites during the study

755 period (November 2013 - July 2014). Riparian vegetation was sampled only during the vegetation season (autumn, summer). 


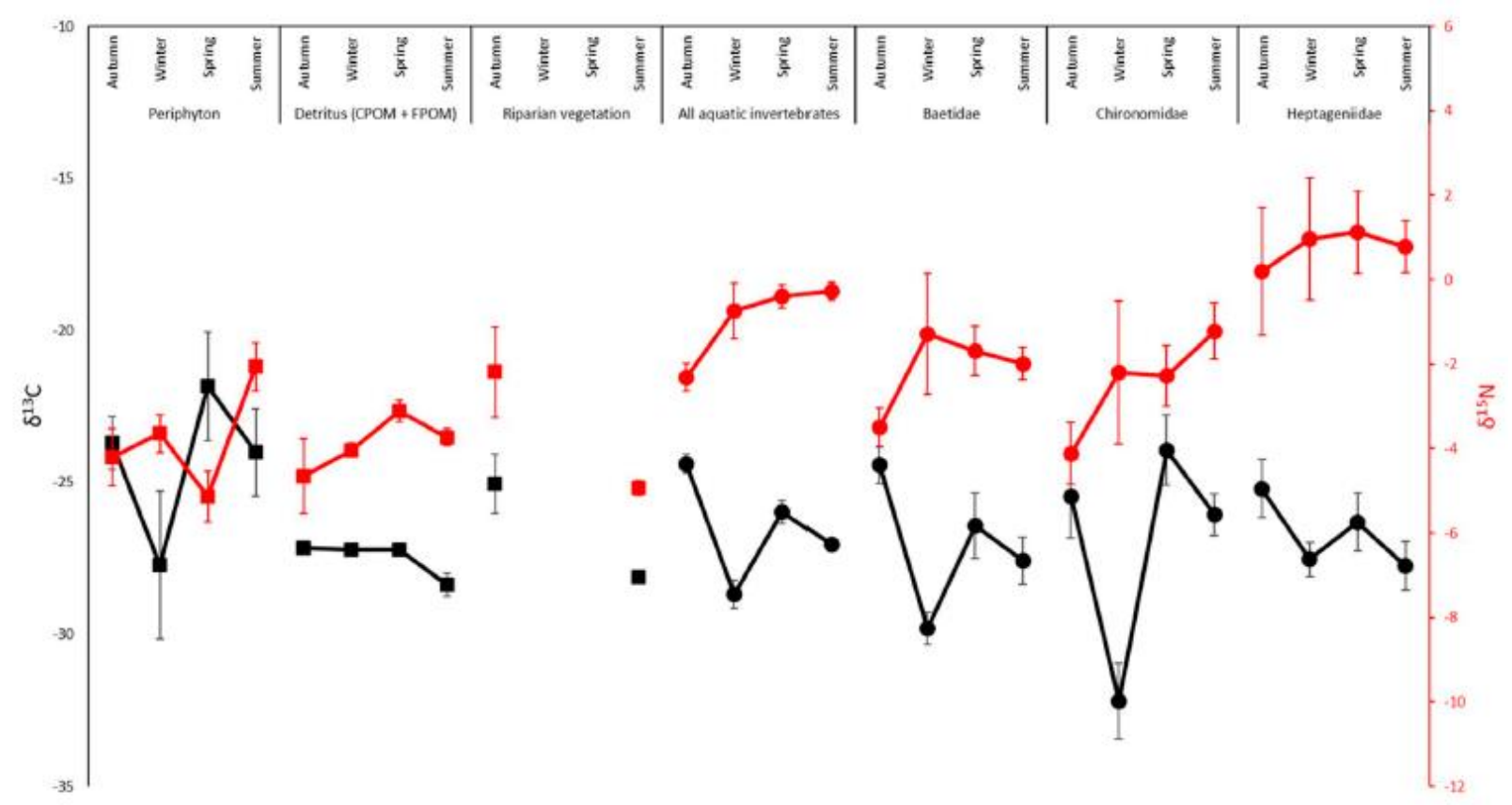

